\title{
1. The current system of fundamental rights protection in the European Union
}

\subsection{ARTICLE 6(1) TEU: THE RECOGNITION OF BINDING LEGAL VALUE TO THE CHARTER OF FUNDAMENTAL RIGHTS OF THE EUROPEAN UNION}

The Charter of Fundamental Rights of the European Union, solemnly proclaimed in December 2000 in Nice by the Presidents of the European Parliament, the Council and the Commission, ${ }^{1}$ acquired binding legal value with the entry into force of the Lisbon Treaty. Therefore, starting from 1 December 2009, the Charter has the same legal ranking as the Treaties, on the basis of what is expressly set forth in Article 6(1) TEU, as amended by Article 1(8) of the Lisbon Treaty. ${ }^{2}$ This provision establishes that:

The Union recognises the rights, freedoms and principles set out in the Charter of Fundamental Rights of the European Union of 7 December 2000, as adapted at Strasbourg, on 12 December 2007, which shall have the same legal value as the Treaties. The provisions of the Charter shall not extend in any way the competences of the Union as defined in the Treaties. The rights, freedoms and principles in the Charter shall be interpreted in accordance with the general provisions in Title VII of the Charter governing its interpretation

1 Following its approval on the 14 October 2000 by the Heads of State and of the Governments of the Member States at the European Council of Biarritz. For its text see [2000] OJ C364/1.

2 The text of the Charter is originally published in an Official Journal ([2007] C303/1) different from and prior to the one that includes the text of the Lisbon Treaty (signed on the 13 December 2007: see OJ C306/1) and the texts of the TEU and of the TFEU therein amended (see [2008] OJ C115/1). Instead, in the following consolidated versions the texts are included in the same Official Journal (for the most recent consolidated version see [2016] OJ C202/1). 
and application and with due regard to the explanations referred to in the Charter, that set out the sources of those provisions. ${ }^{3}$

The first sentence of the new version of Article 6(1) TEU reproduces the first paragraph of Article I-9 of the Treaty establishing a Constitution for Europe, ${ }^{4}$ which, as is known, never entered into force owing to the negative results of the referenda in France and in the Netherlands ${ }^{5}$ in Spring 2005. Differently from what had been decided in 2004 during the drafting of the Constitutional Treaty, the Charter was neither included in the Treaties $^{6}$ nor was it attached to them in a specific Protocol. It is merely referenced in the above-mentioned provision that grants binding nature and primary ranking to it.

This lack of 'incorporation' of the Charter in the Treaties (even in an attached Protocol) and the subsequent lack of formal ratification by the Member States along with the Lisbon Treaty pose quite a few problems regarding the manner through which this legal source can be amended. Of course, the ratification of the Lisbon Treaty 'covers' also the provision in question (better said, the amendments to the provision in question), and therefore it is capable of granting the Charter binding value equal to that of the Treaties. ${ }^{7}$ It is not clear, however, how it could be amended. ${ }^{8}$ The ordinary revision procedure described in Article 48 TEU entailing

3 Emphasis added.

4 Frédéric Sudre, 'Article I-9' in Laurence Burgorgue-Larsen, Anne Levade, Fabrice Picod (eds), Traité établissant une Constitution pour l'Europe. t. 2, La Charte des droits fondamentaux de l'Union (Bruylant 2005) 141.

5 Leonard FM Besselink, 'Constitutional referenda in the Netherlands: a debate in the margin' in Sjef van Erp, Lars Peter Wunibald van Vliet (eds), Netherlands Reports to the Seventeenth International Congress of Comparative Law (Intersentia 2006) 349; Ingolf Pernice, 'Référendum sur la Constitution pour l'Europe: conditions, risques et implications' in Christine Kaddous, Andreas Auer (eds), Les principes fondamentaux de la Constitution européenne (Bruylant 2006) 301.

6 See part II of the Constitutional Treaty, referenced in its Article 9(1) and inclusive of Articles from II-61 to II-114, corresponding to the 54 Articles of the Charter.

7 For a detailed analysis of the legal value of the Charter after the Lisbon Treaty see Lucia Serena Rossi, "Same Legal Value as the Treaties"? Rank, Primacy, and Direct Effects of the EU Charter of Fundamental Rights' (2017) 18 German Law Journal 771.

8 On the legal value of the Charter according to Article 6(1) TEU (with a specific analysis of the issues related to its revision and to the lack of ratification by the Member States) see Luigi Daniele, 'Carta dei diritti fondamentali dell'Unione europea e Trattato di Lisbona' (2008) 13 DUE 655. 
the involvement of the Convention, as established in its paragraph 3 (although differently composed than the one that produced the text of the Charter in $2000^{\circ}$ ) and the ratification by the Member States (paragraph 4) could be followed. At this point it might be advisable to include the 'updated' Charter in a specific Protocol annexed to the Treaties.

Alternatively, if the decision were not to amend its current peculiarities, a body that is similar or identical in its composition to the one which drafted the Charter in 2000 could be entrusted with the amendments. In this case, it would still seem indispensable to amend Article 6(1) TEU so that it mentions, along with the re-proclamation of the Charter in Strasbourg, also the role of that body for revisions. In order for it to be effective after its amendment, the Member States would need to ratify the revision made to Article 6 TEU under Article 48 TEU (possibly without the intervention of the Convention referred to in its paragraph 3 ). However, the 'Masters of the Treaties' may very well choose different paths from the ones indicated and only what happens in practice will be able to provide a clear response to the question raised by the peculiar process of drawing up the Charter and by the decision not to include it 'within' the Treaties, or even as an attachment to the Treaties.

As mentioned above, in order to grant 'constitutional' 10 status to the Charter through the reference in paragraph 1, Article 6 TEU, the Charter underwent certain readjustments that were referenced in the disposition in question. However, the fact that it had binding effects equal to the ones of the Treaties only starting from 1 December 2009 does not mean that prior to that date no kind of legal value was recognized to it. The Charter has always been considered more than a simple act of soft law, even before acquiring binding legal value. Moreover, according to the original version, from the very beginning the Charter was drafted 'as if' it was meant to acquire binding nature 'in view of its inclusion in the Treaties'. ${ }^{11}$

9 On this Convention and its preparatory work see Roberto Adam, 'Da Colonia a Nizza: la Carta dei diritti fondamentali dell'Unione europea' (2000) 5 DUE 882; Gráinne de Búrca, 'The Drafting of the European Union Charter of Fundamental Rights' (2001) 26 E L Rev 126.

10 Xavier Groussot, Laurent Pech, 'Fundamental Rights Protection in the European Union post Lisbon Treaty' <http://www.robert-schuman.eu/en/doc/ questions-d-europe/qe-173-en.pdf>, 14 June 2010, 1, 2.

11 See the speech of the President of the above-mentioned Convention, Roman Herzog, held on the 17 December 1999, Document-Charte 4105/00, attachment No. 1. 
From the first months following its proclamation, the Charter was being used by the General Court (at the time Court of First Instance) and by the Advocates General as an argument a fortiori to emphasize solutions or principles justified or set forth by other EU provisions. ${ }^{12}$ The ECJ, instead, used it in such a way from 2006.13 Among the several decisions of the Court of First Instance that mention the Charter, noteworthy is the one delivered on 30 January 2002, i.e. max. mobil $v$ Commission, ${ }^{14}$ where it seems that the EU Judges recognize that such a source has binding value. In fact, in the preliminary remarks they state that Article 41 CFR 'confirms that each individual has the right to have the issues concerning him or her addressed in an impartial and equal way and within reasonable time by the institutions and the bodies of the Union'. The merely 'confirmatory' nature that has been given to the Charter seems singularly in contrast to the sole indication of Article 41 CFR as legal basis to admit that individuals are entitled to the right in question.

Therefore, the political institutions whose Presidents proclaimed the Charter in 2000 have considered themselves bound, as a matter of fact,

12 See, e.g. Case C-173/99 BETCU ECLI:EU:C:2001:356, Opinion of AG Tizzano, paras 26 f; Case C-208/00 Uberseering ECLI:EU:C:2002:632, Opinion of AG Ruiz-Jarabo Colomer, para 59; Case C-50/00 Unión de Pequeños Agricultores v Council ECLI:EU:C:2002:462, Opinion of AG Jacobs, para 39; Case T-112/98 Mannesmannröhren-Werke v Commission ECLI:EU:T:2001:61, para 76; Case T-177/01 Jégo-Quéré v Commission ECLI:EU:T:2002:112, paras 42 and 47; Joined Cases T-116/01 and T-118/01 $P$ \& $O$ European Ferries (Vizcaya) v Commission ECLI:EU:T:2003:217, para 209.

13 Case C-540/03 European Parliament v Council ECLI:EU:C:2006:429, para 38, and, subsequently, Case C-432/05 Unibet ECLI:EU:C:2007:163, para 37; Case C-303/05 Advocaten voor de Wereld ECLI:EU:C:2007:261, para 46; Case C-244/06 Dynamic Medien ECLI:EU:C:2008:85, para 41. For a detailed analysis of the use of the Charter by the ECJ even before it acquired binding legal value and for the first approaches of the jurisprudence after the entry into force of the Lisbon Treaty see Monica Lugato, 'La rilevanza giuridica della Carta dei diritti fondamentali dell'Unione europea' (2002) 85 Riv Dir Int 1; Ugo Villani, 'I diritti fondamentali tra Carta di Nizza, Convenzione europea dei diritti dell'uomo e progetto di Costituzione europea' (2004) 9 DUE 73; Giacomo Di Federico (ed.), The EU Charter of Fundamental Rights. From Declaration to Binding Instrument (Springer 2011); Allan Rosas, Heidi Kaila, 'L'application de la Charte des droits fondamentaux de l'Union européenne par la Cour de justice: un premier bilan' (2011) 16 DUE 1; Lara Trucco, Carta dei diritti fondamentali e costituzionalizzazione dell'Unione europea. Un'analisi delle strategie argomentative e delle tecniche decisorie a Lussemburgo (Giappichelli 2013).

14 Case T-54/99 ECLI:EU:T:2002:20, paras 48 and 57. 
by its provision since that date, and the Charter is normally referenced as a parameter of legality in the acts of secondary law that have been adopted after its proclamation. ${ }^{15}$

In any event, the formal acquisition of binding nature is unanimously considered among scholars an essential qualitative step, a real turning point in the European integration process, since the protection of fundamental rights is permanently placed at the centre of the EU legal system. ${ }^{16}$ This approach is also confirmed by the ECJ that, in the famous Opinion 2/13 regarding the accession of the Union to the ECHR, set forth that the EU system is

a structured network of principles, rules and mutually interdependent legal relations linking the EU and its Member States, and its Member States with each other, which are now engaged, as is recalled in the second paragraph of Article $1 \mathrm{TEU}$, in a 'process of creating an ever closer union among the peoples of Europe'. This legal structure is based on the fundamental premiss that each Member State shares with all the other Member States, and recognises that they share with it, a set of common values on which the EU is founded, as stated in Article 2 TEU. That premiss implies and justifies the existence of mutual trust between the Member States that those values will be recognised and, therefore, that the law of the EU that implements them will be respected. Also at the heart of that legal structure are the fundamental

15 See, e.g. Recital No. 37 of Regulation (EC) No. 1/2003 on the implementation of the rules on competition laid down in Articles 81 and 82 of the Treaty [2003] OJ L1/1; and Recital No. 12 of Framework Decision 2002/584/GAI on the European arrest warrant and the surrender procedures between Member States [2002] OJ L190/1. It is worth remembering that the first act where the three political institutions formally recognized the need to ensure the protection of fundamental rights in the Community legal system, undertaking to respect them in discharging their duties, is the Joint Declaration of the European Parliament, the Council and the Commission on Fundamental Rights of the 5 April 1977 [1977] OJ C103/1. This act was followed by the Resolution by the European Parliament of the 12 April 1989 adopting the Declaration of Fundamental Rights and Freedoms [1989] OJ C120/51.

16 Sonia Morano-Foadi, Stelios Andreadakis, 'Reflection on the Architecture of the EU after the Treaty of Lisbon: The European Judicial Approach to Fundamental Rights' (2011) 17 ELJ 595, 599; Sara Iglesias Sanchez, 'The Court and the Charter: the impact of the entry into force of the Lisbon Treaty on the ECJ's approach to fundamental rights' (2012) 49 CML Rev 1565, 1566; Luc Weitzel, 'La Charte des droits fondamentaux de l'Union européenne, avancée ou régression?' in Luc Weitzel (ed.), L'Europe des droits fondamentaux. Mélanges en hommage à Albert Weitzel (Pedone 2013) 225, 250. 
rights recognised by the Charter (which, under Article 6(1) TEU, has the same legal value as the Treaties). ${ }^{17}$

The respect for those rights is 'a condition of the lawfulness of EU acts, so that measures incompatible with those rights are not acceptable in the EU'.18

Therefore, today the Charter represents the very identity of the EU and constitutes its 'written parameter of constitutionality', as already highlighted by Advocate General Bot in the Opinion of the Scattolon case, where he states that:

Since the Charter (...) occupies a central place in the system of protection of fundamental rights in the Union, it must, in my opinion, constitute the reference legislation each time the Court is called upon to rule on the compliance with an EU measure or a national provision with the fundamental rights protected by the Charter. ${ }^{19}$

It is a parameter of legality, as well as of interpretation, and it binds, along with the EU Judges, the other institutions, bodies, offices and agencies of the Union as well as the Member States when they implement the EU law, as specified by Article 51(1) CFR. ${ }^{20}$ Again, with

17 Opinion 2/13 Adhésion de l'Union à la CEDH ECLI:EU:C:2014:2454, paras 167-169 (emphasis added).

18 Ibid., para 169.

19 Case C-108/10 ECLI:EU:C:2011:542, Opinion of AG Bot, para 108 (emphasis added).

20 On the scope of application of the Charter see Koen Lenaerts, 'Exploring the Limits of the EU Charter of Fundamental Rights' (2012) 8 EuConst 365; id., 'The EU Charter of Fundamental Rights: Scope of Application and Methods of Interpretation' in Vincent Kronenberger, Maria Teresa D'Alessio, Valerio Placco (eds), De Rome à Lisbonne: les juridictions de l'Union européenne à la croisée des chemins. Hommage en l'honneur de P. Mengozzi (Bruylant 2013) 107; Thomas von Danwitz, Katherina Paraschas, 'A Fresh Start for the Charter: Fundamental Questions on the Application of the European Charter of Fundamental Rights' (2012) 35 Fordham Int'l L J 1396; Emily Hancox, 'The Meaning of "Implementing" EU Law under Article 51 (1) of the Charter: Akerberg Fransson' (2013) 50 CML Rev 1411; Daniel Sarmiento, 'Who's Afraid of the Charter? The Court of Justice, National Courts and the New Framework of Fundamental Rights Protection in Europe' in Kronenberger, D'Alessio, Placco (eds), 1267; Bas van Bockel, Peter Wattel, 'New Wine into Old Wineskins: the Scope of the Charter of Fundamental Rights of EU after Aglakaren v. Hans Fransson' (2013) 38 E L Rev 874; Antonio Tizzano, 'L'application de la Charte des droits fondamentaux dans les États membres à la lumière de son article 51, paragraphe 1' (2014) 19 DUE 429; Michael Dougan, 'Judicial Review of 
reference to the provisions to which the ECJ recognizes direct horizontal effect, they directly bind individuals. ${ }^{21}$

The above-mentioned qualitative step that creates this new era of integration, based on fundamental rights, is without a doubt relevant (at least) from the point of view of the visibility of the protected rights, visibility that is, after all (along with legal certainty) one of the goals pursued with the drafting of the Charter, ${ }^{22}$ and visibility that is, however, in a certain sense 'betrayed' or in any event frustrated or not fully

Member State Action under the General Principles and the Charter: Defining the "Scope of Union Law" (2015) 52 CML Rev 1201; Paolo Mengozzi, 'La rilevanza giuridica e l'ambito di applicazione della Carta alla luce della giurisprudenza della Corte di giustizia' (2015) 10 Studi sull'integrazione europea 23; Bruno Nascimbene, 'Il principio di attribuzione e l'applicabilità della Carta dei diritti fondamentali: l'orientamento della giurisprudenza' (2015) 98 Riv Dir Int 49; Ulf Bernitz, 'The Scope of the Charter and its Impact on the Application of the ECHR. The Akerberg Fransson Case on Ne Bis in Idem in Perspective' in Sybe de Vries, Ulf Bernitz, Stephen Weatherill (eds), The EU Charter of Fundamental Rights as a Binding Instrument: Five Years Old and Growing (Hart 2015) 155; Clara Rauchegger, 'The Interplay Between the Charter and National Constitutions after Akerberg Fransson and Melloni. Has the CJEU Embraced the Challenges of Multilevel Fundamental Protection?' Ibid., 93.

21 Some provisions of the Charter, by their nature, can only have direct vertical effect (see, e.g. the right to good administration, the right to a fair trial, or the ne bis in idem principle, referred to in Articles 41, 47 and 50 CFR). The direct horizontal effect has today been recognized, besides to the principle of non-discrimination on the ground of sex (see Case 43/75 Defrenne $v$ SABENA ECLI:EU:C:1976:56), only to the principle of non-discrimination on the ground of age, as a general principle of law (Case C-144/04 Mangold ECLI:EU: C:2005:709; Case C-555/07 Kücükdeveci ECLI:EU:C:2010:21; Case C-441/14 Dansk Industri ECLI:EU:C:2016:278: see Elena Gualco, Luisa Lourenço, "“Clash of Titans". General Principles of EU Law: Balancing and Horizontal Direct Effect' (2016) 1 European Papers 643), set forth in Article 21 CFR (Case C-143/16 Abercrombie \& Fitch Italia ECLI:EU:C:2017:566: see ch 2 n 204). On the horizontal effect of the Charter see Eleni Frantziou, 'The Horizontal Effect of the Charter of Fundamental Rights of the EU: rediscovering the Reasons for Horizontality' (2015) 21 ELJ 657. On the scope of application ratione personae of the Charter see Xavier Groussot, Laurent Pech, Gunnar Thor Petursson, 'The Reach of EU Fundamental Rights on Member State Action after Lisbon' in Sybe de Vries, Ulf Bernitz, Stephen Weatherill (eds), The Protection of Fundamental Rights in the EU After Lisbon (Hart 2013) 97.

22 Lucia Serena Rossi, 'Les rapports entre la Charte des droits fondamentaux et le traité de Lisbonne' in Chemins d'Europe: mélanges en l'honneur de Jean-Paul Jacqué (Lgdj 2010) 609, 620, states that the drafting of a written catalogue of fundamental rights gives citizens an instrument in which they can find a 'common sense of identity'; Rosas, Kaila (n 13) 9. 
fulfilled. As correctly highlighted by scholars, it is in fact a contradiction that the Charter is not at least attached to the Treaties in an ad hoc Protocol, but only referenced in Article 6 (1)TEU. ${ }^{23}$ Another contradiction and source of uncertainty, or in any event of a lack of clarity and coherence, is the fact that a Protocol and four Declarations regarding the Charter or regarding the positions of certain States with respect to the Charter are annexed to the Treaties (see Protocol No. 30 on the application of the Charter of Fundamental Rights of the European Union to Poland and to the UK; Declaration No. 1 concerning the Charter of Fundamental Rights of the European Union; Declaration No. 53 by the Czech Republic on the Charter of Fundamental Rights of the European Union; Declaration No. 61 by the Republic of Poland on the Charter of Fundamental Rights of the European Union; Declaration No. 62 by the Republic of Poland concerning the Protocol on the application of the Charter of Fundamental Rights of the European Union in relation to Poland and the UK). Moreover, a deficit of legal certainty is detected in the wording of many provisions of the Charter and, in particular, in the unclear distinction between rights and principles, from which Article 52(5) CFR derives significant legal consequences. ${ }^{24}$

\subsection{THE CONTENT OF THE CHARTER OF FUNDAMENTAL RIGHTS}

The Charter consists of 54 Articles and is subdivided into seven titles respectively dedicated to 'Dignity' (Title I, Articles 1-5), 'Freedoms' (Title II, Articles 6-19), 'Equality' (Title III, Articles 20-26), 'Solidarity' (Title IV, Articles 27-38), 'Citizen's Rights' (Title V, Articles 39-46), 'Justice' (Title VI, Articles 47-50) and 'General Provisions Governing the Interpretation and Application of the Charter' (Title VII, Articles 51-54). The first six titles largely correspond to the values set forth in Article 2 TEU. The last title includes four 'horizontal' or 'transversal' provisions, that, as Article 6(1) TEU specifies, are to be used for the correct interpretation and application of the 'material' provisions of the Charter (i.e. the rights, principles and freedoms set forth in the first six titles). For such a purpose the Explanations relating to the Charter, referenced in the above-mentioned disposition, as well as in the Preamble to the Charter (which recalls how they were "prepared under the authority

\footnotetext{
23 Rosas, Kaila (n 13) 9.

24 See ch 22.7.
} 
of the Praesidium of the Convention which drafted the Charter and updated under the responsibility of the Praesidium of the European Convention') and in paragraph 7 of its Article 52, constitute a valid aid both for the EU Judges and for those of the Member States. The Explanations include the reference to the sources of inspiration of the provisions of the Charter and, although not covered by the proclamation (along with the Charter) and thus formally lacking binding legal effect, they must in any case be taken in due consideration when interpreting the Charter. This obligation precisely stems from both Article 52(7) CFR and Article 6(1) TEU. The Explanations, combined with the binding provisions that they interpret, allow for hermeneutic results unexpected on the basis of the analysis of the sole mandatory provision. ${ }^{25}$

It is the very Preamble to the Charter therefore that reminds us that:

This Charter reaffirms, with due regard for the powers and tasks of the Union and for the principle of subsidiarity, the rights as they result, in particular, from the constitutional traditions and international obligations common to the Member States, the [ECHR], the Social Charters adopted by the Union and by the Council of Europe and the case-law of the Court of Justice of the European Union and of the European Court of Human Rights. ${ }^{26}$

25 Reference is made, in particular, to Article 52(3) CFR and to the pertinent Explanations. See further ch 22.1 and ch 44.7. On the Explanations and their scope see Jean-Paul Jacqué, 'The Explanations Relating to the Charter of Fundamental Rights of the European Union' in Steve Peers, Tamara Hervey, Jeff Kenner, Angela Ward (eds), The EU Charter of Fundamental Rights. A Commentary (Hart 2014) 1715.

26 Emphasis added. In this sense see also Recital No. 6 of the Preamble to Protocol No. 30 attached to the TEU and to the TFEU (see ch 44.4). Niilo Jääskinen ('The Place of the EU Charter within the Tradition of Fundamental and Human Rights' in Sonia Morano-Foadi, Lucy Vickers (eds), Fundamental Rights in the EU. A Matter for Two Courts (Hart 2015) 11, 17) identifies as sources of the rights set forth in the Charter 'the ECHR, the European Social Charter together with the Community Charter of the Fundamental Social Rights of Workers, and the EU law, the latter comprising the treaties, secondary legislation and the case law of the CJEU. Moreover, some individual provisions are derived from other international human rights instruments: Article 1 of the Charter on human dignity stems from the UN Universal Declaration of Human Rights, Article 24 of the Charter from the UN Convention of the Rights of the Child, Article 18 of the Charter from the Geneva Refugee law convention and Articles 3 and 8 of the Charter from Council of Europe sectorial instruments relating respectively to bioethics and data protection'. On the substantial lack of originality of the Charter, see Pierre Pescatore, 'La coopération entre la Cour communautaire, les juridictions nationales et la Cour européenne des droits de 
The Charter thus substantially reproduces in a written catalogue the general principles of law set forth by the ECJ in its jurisprudence, developed over the years. ${ }^{27}$ Such general principles have been for the most part codified and, to a small extent, crystallized, in the sense that with reference to some of them - although recognized at a domestic or international level or in nuce in the jurisprudence of the ECJ - it is only their inclusion in the Charter that determines their final consecration as binding 'principles' or 'rights' in the EU legal system. ${ }^{28}$ For example, the right to the protection of personal data, foreseen in Article 8 CFR (although based inter alia on Article 8 ECHR, ${ }^{29}$ as provided for in the Explanations relating to the Charter); the prohibition of the reproductive cloning of human beings, provided in Article 3(2)(d) CFR; and, the right to paid annual leave provided in Article 31(2) CFR are all considered crystallized and not simply codified. ${ }^{30}$

One may wonder whether all of the general principles concerning fundamental rights developed over the decades by the ECJ are in fact in the Charter or whether some of them might not have been included. The reference is, for example, to the duty of care of the EU Administration towards its officials. ${ }^{31}$

l'homme dans la protection des droits fondamentaux' (2003) Revue du Marché commun et de l'Union européenne 151, $154 \mathrm{ff}$.

27 See this ch 1.3-1.5.

28 As mentioned, the distinction between principles and rights in the Charter is not clear at all. On this topic see ch 22.7 .

29 Moreover, in the sense that 'Article 8 of the Charter concerns a fundamental right which is distinct from that enshrined in Article 7 of the Charter and which has no equivalent in the ECHR' see Joined Cases C-203/15 and C-698/15 Tele2 Sverige and Watson ECLI:EU:C:2016:970, para 129.

30 For its qualification as a general principle of law, following an analysis of the relevant international and Community sources, concluding that 'the Charter provides us with the most reliable and definitive confirmation of the fact that the right to paid annual leave constitutes a fundamental right' see Case C-173/99 BETCU ECLI:EU:C:2001:356, Opinion of AG Tizzano, paras 22-28. In the sense that also the 'right to preventive health care' would seem to be new with respect to the previous legal contours of general principles of law see Groussot, Pech (n 10) 5. In the sense that also 'the right to access to health care' and 'the rights of the elderly' are considered a change compared with the protection guaranteed by the ECHR see George Arestis, 'Fundamental Rights in the EU: Three Years after Lisbon, the Luxembourg Perspective' <file://C:/Users/hp/ Downloads/researchpaper_2_2013_arestis_lawpol_final.pdf> 1, 3.

31 See further Thomas Livolsi, 'Le devoir de sollicitude dans le contentieux récent de la fonction publique de l'Union européenne' (2014) $25 R$ A E 369. 
This issue will be analysed below, ${ }^{32}$ along with the possibility of defining new - and autonomous - general principles developed by the ECJ after the drafting of the Charter and not included in it. However, it is worth stressing here that in the current EU legal framework the general principles of law protecting fundamental rights should not be assigned a mere so-called 'residual' role, however important this role is for a further development of the European integration process. The different functions attributable, even today, to this unwritten source of law, albeit in the presence of a written catalogue of rights, will be analysed in particular in the last chapter of this work.

\subsection{ARTICLE 6(3) TEU: THE GENERAL PRINCIPLES OF LAW CONCERNING FUNDAMENTAL RIGHTS}

The general principles of law constitute the ultimate unwritten source of law of the EU legal system. The other unwritten source of law that binds the European Union, like any other subject of international law, is of course customary international law. ${ }^{33}$

No definition of such a category of sources or even less a list of them, more or less exhaustive, can be detected in the founding Treaties. This fact is coherent with the (even creative) function that has always been attributed to the Court of Justice - final interpreter of the Treaties (see Article 19 TEU, former Article 220 EC, and former Article 164 EEC) (i) to identify the existence of such general principles of law as defining and structural elements of the Union and (ii) to outline their boundaries.

However, the 'fluidity' of the notion of 'general principle' is elusive and cannot be construed on the basis of clear parameters; neither can it be described as a set of provisions having specific features or satisfying certain requirements set forth in the Treaties. This sometimes implies certain difficulties in their exact identification. As correctly noted in legal literature ${ }^{34}$ they therefore seem to be identifiable and definable more by notions relating to the philosophy of law than by notions pertaining to

\footnotetext{
32 See ch 44.5.

33 Case C-162/96 Racke ECLI:EU:C:1998:293, paras 45 f; Joined Cases C-402/05 P and C-415/05 P Kadi and Al Barakaat International Foundation v. Council and Commission ECLI:EU:C:2008:461, para 291; Case C-364/10 Hungary v Slovakia ECLI:EU:C:2012:630, para 44.

34 Norberto Bobbio, 'Principi generali di diritto' (1966) Novissimo Digesto italiano XIII 887; Giorgio Gaja, 'Principi generali del diritto (diritto internazionale)' (1986) Enciclopedia del diritto XXXV 535.
} 
EU law. The notion of 'general principle' is, in fact, a transversal concept that is neither typical nor limited to the legal system in question, except for the fact that, as all legal systems (domestic and international), it is characterized by its own principles.

In this perspective, the principles can therefore be considered provisions (prescriptive statements aimed at guiding behaviours) that become peculiarly relevant within the system of reference, being: (i) fundamental provisions that can be considered as the backbone of the system of sources; (ii) flexible, as lacking a precise linguistic structure (in fact normally not written); and (iii) general, as constituting the rationale of numerous provisions of secondary law.

It follows from the above that the functions of this category of sources are several. For instance, the general principles confer unity, coherence and homogeneity to the legislative system of the Union, integrating the sector-based nature of the Treaties and filling their gaps. Therefore, they can be used as criteria of interpretation, often representing limits to the exercise of the powers of the EU institutions in relation to the legal status of individuals. Further, they constitute a parameter of legality of acts and conducts of both the institutions and the Member States, since the violation of the principles entails the risk of annulment of secondary law (through an action for annulment or a reference for a preliminary ruling on the validity); the possible censure of State acts or omissions (through an infringement procedure or, indirectly, through a reference for a preliminary ruling on the interpretation ${ }^{35}$ ); as well as the finding of a non-contractual liability of the institutions (through an action before the EU Judge) or the Member States (through an assessment by the domestic judge).

Certain general principles have been identified by the ECJ $(i)$ on the basis of a process of interpenetration, osmosis and mutual influence, meaning that the EU legal system has adopted rights established by international sources (in primis, as we shall see, the ECHR) and national principles, inferring them from the legal background common to the

35 Although, as is known, the preliminary ruling is aimed, first of all, at providing the correct interpretation of a EU provision, through such proceedings the ECJ effectively also delivers a judgment on the compatibility of the national relevant law with the EU law. Regarding the complementary relationship between the infringement procedure and a preliminary ruling on the interpretation see Case 26/62 Van Gend \& Loos ECLI:EU:C:1963:1; Case 31/69 Commission v Italy ECLI:EU:C:1970:10; Joined Cases 142/80 and 143/80 Amministrazione delle finanze dello Stato $v$ Essevi and Salengo ECLI:EU:C: 1981:121. 
plurality of legal systems of the Member States. Other general principles have been established (ii) on the basis of a process of induction, abstraction and generalization, starting from an analysis of substantive provisions of the primary and secondary EU law and verifying the rationale that binds them together, the principles being, as seen, general provisions that constitute the raison d'être of many specific provisions.

The only provision of the Treaties that mentions the general principles as sources of the EU law is Article 6(3) TEU (Article 340(2) TFEU, instead, refers to 'general principles common to the laws of the Member States' with respect to the EU provisions regulating non-contractual liability), and the reference regards only the general principles concerning fundamental rights, on which we will concentrate our attention in the following pages. The analysis of such provision before the previous paragraph 2 of the same Article is justified by the fact that it has been included in the Treaties since Maastricht (1992), while the latter has been included, as is known, only with the Lisbon revision, that has introduced the legal basis for the accession of the European Union to the ECHR. ${ }^{36}$

The Maastricht Treaty 37 codified in the former Article F.2 TEU which became Article 6(2) TEU with the Amsterdam Treaty and Article 6(3) TEU with the Lisbon Treaty - the creative (as mentioned) jurisprudence of the $\mathrm{ECJ}^{38}$ not incorrectly named 'fabrique du droit de l'Union européenne'. ${ }^{39}$

36 See this ch 1.7.

37 It should be noted that already in the Preamble to the Single European Act ([1987] OJ L169/1) the Member States declare to be 'determined to work together to promote democracy on the basis of the fundamental rights recognized in the constitutions and laws of the Member States, in the Convention for the Protection of Human Rights and Fundamental Freedoms and the European Social Charter, notably freedom, equality and social justice' (emphasis added).

38 It is well known that the jurisprudence of the ECJ is creative not only with respect to the protection of the fundamental rights of the individual. Reference can be made to the Tchernobyl case, where the Court, despite the wording of Article 173 TEEC, recognized the right of the European Parliament to bring actions for annulment (Case C-70/88 Parliament $v$ Council ECLI:EU:C: 1991:373), or to the more recent case Commission v France (Case C-304/02 ECLI:EU:C:2005:444), where the imposition of a penalty 'and' the payment of a lump sum to the responsible Member State were admitted, despite the fact that, in Article 228(2) TEC the conjunction used was (as still is pursuant to Article 260(2) TFEU) 'or'. See further Mark Dawson, Bruno De Witte, Elise Muir (eds), Judicial Activism at the European Court of Justice (Edward Elgar 2013).

39 See the title of the book by Pascal Mbongo, Antoine Vauchez (eds), Dans la fabrique du droit européen. Scènes, acteurs et publics de la Cour de justice des Communautés européennes (Bruylant 2009). On the ECJ's role in the 
This article, in its current wording as amended in the Lisbon Treaty, sets forth that: 'Fundamental rights, as guaranteed by the European Convention for the Protection of Human Rights and Fundamental Freedoms and as they result from the constitutional traditions common to the Member States, shall constitute general principles of the Union's law' ${ }^{40}$ Its previous formulation, included among the provisions of the Maastricht Treaty, instead stated that: 'The Union shall respect fundamental rights, as guaranteed by the European Convention for the Protection of Human Rights and Fundamental Freedoms (...) and as they result from the constitutional traditions common to the Member States, as general principles of Community law' ${ }^{41}$ This amending intervention operated by the 'Masters of the Treaties' cannot be considered a mere 'aesthetic' revision of the provision of the Treaty instead, as duly noted by scholars, an amendment ensuring 'a firmer anchoring of the fundamental rights in the EU legal order' ${ }^{42}$ definitively (or better said, more clearly) recognizing their primary ranking (even from a formal point of view).

Moreover, although certain scholars had originally denied such ranking to the general principles concerning fundamental rights, ${ }^{43}$ even before the Charter acquired binding nature, the ECJ repeatedly affirmed that they

scrutiny of fundamental rights and, therefore, in the development of the pertinent general principles, see Francesco Capotorti, 'Il diritto comunitario non scritto' (1983) 22 Diritto comunitario e scambi internazionali 409; Anthony Arnull, The General Principles in EEC Law and the Individual (Leicester University Press 1990); Xavier Groussot, General Principles of Community Law (Europa Law 2006); Takis Tridimas, The General Principles of EU Law (2 edn OUP 2006); Koen Lenaerts, José A Gutiérrez-Fons, 'The Constitutional Allocation of Powers and General Principles of EU Law' (2010) 47 CML Rev 1629. More in general, for an historical study of the protection of fundamental rights in the European Union see Francis Jacobs, 'Human Rights in the European Union: The Role of the Court of Justice' (2001) 26 E L Rev 331; Bruno De Witte, 'The Past and the Future Role of the European Court of Justice in the Protection of Human Rights' in Philip Alston (ed.), The EU and Human Rights (OUP 1999) 859.

40 Emphasis added.

41 Ibid.

42 With respect to paragraph 3 of Article I-9 of the Treaty establishing a Constitution for Europe (now Article 6(3) TEU) see Jörg Gerkrath, 'Les principles généraux du droit ont-ils encore un avenir en tant qu'instruments de protection des droits fondamentaux dans l'Union européenne' (2006) $17 R A E$ 31,38 .

43 Giorgio Gaja, 'Identifying the Status of General Principles in European Community Law?' in Scritti in onore di G.F. Mancini (Giuffré 1998) II-445, 446. 
have constitutional status and, indeed, substantive primary ranking. ${ }^{44}$ To confirm such an approach reference could be made to the same wording adopted by the Treaty in referring to them (in truth, in relation to the English version this applies to the pre-Lisbon formulation of the provision ${ }^{45}$ ). In fact, the Union, and even earlier the European Community, according to the jurisprudence established by the ECJ, must respect the fundamental rights 'as general principles' of EU law. The abovementioned Article 6(2) TEU did not specify - just like the current Article 6(3) TEU in its several linguistic versions - whether the fundamental rights had or have to be granted by the Union (i) 'as' principles of Community law, therefore conferring upon them a peculiar and superior ranking compared with the common provisions of secondary law (owing, in primis, to their reference in a primary provision); or (ii) 'because and to the extent that', besides being protected by the constitutions of the Member States and the ECHR, they could or can be represented as general principles of Community law. Owing to the difficulty in identifying the conditions which could permit it to be claimed that fundamental rights are also general principles, the first interpretation has always been preferred, opting for depicting fundamental rights as the core of the category of 'general principles', substantially having primary ranking.

However, it must be stressed that such rights - inferred from the constitutional traditions common to the Member States or from the ECHR (or, as we shall see, from other sources of international law ${ }^{46}$ ) entering into the EU legal order as 'general principles' leaves the Court a broad discretionary power in the identification of such principles and in outlining their boundaries. The approach of the ECJ to the protection of

44 See, e.g. Case C-101/08 Audiolux and Others ECLI:EU:C:2009:626, para 63; Case C-174/08 NCC Construction Danmark ECLI:EU:C:2009:669, para 42; and, more implicitly, Joined Cases C-402/05 P and C-415/05 P Kadi and Al Barakaat International Foundation ECLI:EU:C:2008:461, para 276. In the sense that 'reading an unwritten bill of rights into Community law is indeed the most striking contribution the Court has made to the development of a Constitution for Europe' see Giuseppe F Mancini, 'The Making of a Constitution for Europe' (1989) 26 CML Rev 595, 611.

45 The Italian, French, Spanish, German and Dutch versions continue to use (after Lisbon) the expression 'as general principles' ('in quanto principi generali', 'entant que principes généraux', 'como principios generales', 'sind als allgemeine Grundsätze Teil des Unionsrechts', 'maken als algemene beginselen deel uit van het recht van de Unie'). This suggests that the change operated by the Lisbon Treaty in the English version does not affect the proposed interpretation of (the current formulation of) Article 6(3) TEU.

46 See this ch 1.4 and 1.6. 
fundamental rights has always been aimed at the satisfaction of the specific needs of the EU legal system. This means that a fundamental right protected in the Union 'as general principle' does not necessarily have the same features and the boundaries typical of such a right in the legal system of the Member States or in the ECHR system or in other international systems. ${ }^{47}$

As is known, in a legal system focused on economic integration the ECJ jurisprudence protecting fundamental rights has been developed to react to the so-called counter-limits doctrine, intended to limit the 'absolute primacy'48 of EU law: this in the 'improbable but not impossible'49 event - quoting the Italian Constitutional Court - that an EU provision conflicts with the fundamental principles of the Constitutional law (of a Member State) or with the inalienable rights of the individual. ${ }^{50}$

47 Case 11/70 Internationale Handelsgesellschaft mbH ECLI:EU:C: 1970:114, para 4, stating that: 'The protection of such rights, whilst inspired by the constitutional traditions common to the Member States, must be ensured within the framework of the structure and objectives of the Community' (emphasis added). On the ECJ jurisprudence concerning fundamental rights that is not always in line with the one of the ECtHR see ch 22.4. On the relationship (at least from a formal point of view) between the provisions of the Charter (reaffirming, as indicated above, general principles of law) and the (corresponding) provisions of the ECHR see, in particular, ch 22.1.

48 Armin von Bogdandy, Stephan Schill, 'Overcoming Absolute Primacy: Respect for National Identity Under the Lisbon Treaty' (2011) 48 CML Rev 1417.

49 See expressly Corte Cost., Judgment No. 232/1989 S.p.a. Fragd. For the first development doctrine in question, see Corte cost., Judgment No. 183/1973 Frontini e $a$. The counter-limits doctrine has been formally invoked in Italy for the first time after the decision of the ECJ in Case C-105/14 Taricco and Others ECLI:EU:C:2015:555, when the Constitutional Court, required to decide on matters regarding constitutionality reviews, made a preliminary reference to the ECJ (see Order No. 24/2017, which originated Case C-42/17, M.A.S. and M.B.). On the topic see ch 3 3.7. All of the judgments of the Italian Constitutional Court are available at $<\mathrm{http}: / / \mathrm{www}$. cortecostituzionale.it/actionPronuncia.do $>$.

50 It should be noted that a constitutionality review in circumstances that are substantially identical to those indicated in the text was also provided by the German Constitutional Court. After stating that the European (at the time still Economic) Community suffered from a democratic deficit because of the deficiencies in protecting human rights, in 1974 the Bundesverfassungsgericht held that, as long as (Solange I) the Community does not have a system for the protection of such rights that is adequate compared with the one provided for by the German Fundamental Law, in the event of conflict between secondary Community law and constitutional provisions regarding fundamental rights the 
The intervention of the ECJ, which aims at correcting the flaws in the system and at controlling the counter-limits doctrine by starting 'to take' fundamental rights 'seriously', 51 occurs however within a legal system with its own peculiarities, peculiarities that the Luxembourg Judge must keep in consideration and, in fact, constantly aims at protecting, while interpreting and implementing EU law.

This approach is confirmed by the ECJ in the above-mentioned Opinion $2 / 13,{ }^{52}$ as well as in the Melloni judgment. ${ }^{53}$ Here, because of a harmonization process of the criminal procedural laws of the Member States made by the EU legislator, the Luxembourg Judge stated that, in order to guarantee the effet utile of the cooperation mechanism referred to in the Framework Decision concerning the European Arrest Warrant (EAW), ${ }^{54}$ the mutual trust that distinguishes the relationships between the EU Member States prevails at the highest level of protection of the right

latter shall prevail. Subsequently, in 1979 the same Judge estimated that the constitutional review does not extend to the Community Treaties and, in 1986, it accepted that insofar as the ECJ guarantees an efficient protection of fundamental rights (Solange II) it would refrain from carrying out said review.

51 Jason Coppel, Aidan O'Neill, 'The European Court of Justice: Taking Rights Seriously?' (1992) 29 CML Rev 669, and in reply to this contribution, Nicolas JS Lockhart, Joseph HH Weiler, “Taking Rights Seriously” Seriously: the European Court and its Fundamental Rights Jurisprudence' (1995) 32 CML Rev 51 (Part I), 579 (Part II).

52 Opinion 2/13 Adhésion de l'Union à la CEDH ECLI:EU:C:2014:2454, paras 191-194.

53 Case C-399/11 [2013] ECLI:EU:C:2013:107. See Nik De Boer, 'Addressing rights divergence under the Charter: Melloni' (2013) 50 CML Rev 1083; Edouard Dubout, 'Le niveau de protection des droits fondamentaux dans l'Union européenne: unitarisme constitutif versus pluralisme constitutionnel. Réflexions autour de l'arrêt Melloni' (2013) 49 C D E 293; Dominique Ritleng, 'De l'articulation des systèmes de protection des droits fondamentaux dans l'Union. Les enseignements des arrêts Åkerberg Fransson et Melloni' (2013) RTDE 267; John Vervaele, 'The European Arrest Warrant and Applicable Standards of Fundamental Rights in the EU' (2013) 6 Review of European Administrative Law 37; Vassilios Skouris, 'Développements récents de la protection des droits fondamentaux dans l'Union européenne: les arrêts Melloni et Åkerberg Fransson' (2013) 18 DUE 229; Leonard FM Besselink, 'The Parameters of Constitutional Conflict After Melloni' (2014) 39 E L Rev 531; Asteris Pliakos, Georgios Anagnostaras, 'Fundamental Rights and the New Battle over Legal and Judicial Supremacy: Lessons from Melloni' (2015) 34 YEL 97. For additional Italian bibliographycal references see Chiara Amalfitano, 'Mandato d'arresto europeo: reciproco riconoscimento vs diritti fondamentali?' < http://www.penale contemporaneo.it/>, 4 July 2013.

54 See above n 15. 
to due process according to the specificities of the Spanish constitutional system relevant in the case at issue. ${ }^{55}$

In any event, although with certain 'limitations' or 'attenuations' or 'particular boundaries' owing to the specific features of the legal system in question, it is undeniable that the protection of fundamental rights through the general principles has allowed the advancement of the European integration process. By developing the general principles "the Court has actually added flesh to the Community law, which otherwise being a legal order based on a framework Treaty - would have remained a mere skeleton of rules, not quite constituting a proper legal "order"" ${ }^{56}$

Therefore, the interpretative work of the ECJ has avoided the risk of a breakdown in the supranational legal system, turning the 'counter limits' from a potentially destructive factor into a factor of propulsion and enrichment of the EU legal system. ${ }^{57}$ This is achieved through a constant process of osmosis, a progressive convergence of values and their virtuous interaction, by means of a so-called bottom-up effect (according to which a certain principle is inferred by the common constitutional traditions and elevated to European constitutional heritage) and by means of a so-called top-down effect (according to which the ECJ, through the general principle, imposes the same level of protection of fundamental rights on all Member States, even those that did not recognize such

55 Case C-399/11 Melloni ECLI:EU:C:2013:107, paras 55-64, para 63. For a partial mitigation of the approach followed by the ECJ in the Melloni case, or for a better definition of such approach - being necessary to ensure the protection, in the case at issue, of the fundamental rights of the individual (that instead was already adequately ensured in the Melloni case) see the more recent decision in Joined Cases C-404/15 and C-659/15 PPU Aranyosi and Căldăraru ECLI:EU:C:2016:198, para 104.

56 Case C-411/05 Palacios de la Villa ECLI:EU:C:2007:604, Opinion of AG Mazák, para 85.

57 Similarly see Chiara Amalfitano, Massimo Condinanzi, Unione europea: fonti, adattamento e rapporti tra ordinamenti (Giappichelli 2015) 176; Giuseppe Tesauro, 'Costa/Enel: qualche riflessione col senno di oggi', and Massimo Condinanzi, 'I controlimiti come sintesi ideale tra primato da affermare e identità nazionale da rispettare' in Bruno Nascimbene (ed.), Costa/Enel: Corte costituzionale e Corte di giustizia a confronto, cinquant'anni dopo (Giuffrè 2015) respectively 55, 65 and 119,123 . On a 'positive function' of the counter-limits doctrine, aimed at a 'dialectical confrontation' among the ECJ and the national Constitutional Courts for the identification of the highest degree of protection of fundamental rights, see Antonio Tizzano, 'La protection des droits fondamentaux en Europe: la Cour de justice et les juridictions constitutionnelles nationales' (2006) 16 Revue du droit de l'Union européenne 9, 17. 
principles, thereby affecting their national legislative and judiciary systems). ${ }^{58}$ The result is a constant increase in the level of protection of certain rights/values not only in the Union, but also in those Member States that may not have protected that right/value or did not protect it in accordance with the specificities established by the ECJ. ${ }^{59}$

This work of interpretation appears useful, if not indeed essential, even though the Union has its own written catalogue of rights and principles. In fact, if the Charter enhances the visibility of the rights and principles set forth therein, giving them greater relevance and certainty, the creative role of the ECJ injects flexibility into the system, allowing for a constant enrichment and evolutive adjustment of those rights and principles in view (and by reason) of the advancement of the integration process, thereby avoiding their ossification.

As already anticipated, the position upheld by some according to which the general principles of law concerning fundamental rights have a merely alternative function, and their role in the EU legal system is now only residual, cannot be accepted.60 This is particularly so if being 'residual' has a reductive and almost degrading, dismissive meaning, as certain authors seem to argue by characterizing the provision of Article 6(3) TEU as obsolete, maintaining, in fact, that the interpretative and

58 On the bottom-up and top-down effects, see Koen Lenaerts, José A Gutiérrez-Fons, 'The Role of General Principles of EU Law' in Anthony Arnull, Catherine Barnard, Michael Dougan, Eleanor Spaventa (eds), A Constitutional Order of States?: Essays in EU law in Honour of Alan Dashwood (Hart 2011) 179. Alonso R García ('The General Provisions of the Charter of Fundamental Rights of the European Union' (2002) 8 ELJ 492, 513) proposes, besides an interpretation of national law by Member States that is pro communitate, also an interpretation of the EU law by the ECJ that is pro constitutione of the Member States.

59 In the event a national constitutional value is substantially recognized as a general principle of EU law or, in any case, as a value protectable within the EU legal order, albeit with the possibility for a Member States to ensure a more specific level of protection of the right relevant from time to time see Case C-36/02 Omega ECLI:EU:C:2004:614; Case C-244/06 Dynamic Medien ECLI: EU:C:2008:85; Case C-208/09 Sayn-Wittgenstein ECLI:EU:C:2010:806.

60 Louis Dubouis, 'Les principes généraux du droit communautaire, un instrument périmé de protection des droits fondamentaux?' in Les mutations contemporaines du droit public. Mélanges en l'honneur de Benoît Jeanneau (Dalloz 2002) 77, 89, although reaffirming the irreplaceable function of the general principles for the integration of the EU legal system. Gerkrath (n 42) 42 qualifies the general principles of law as 'source subsidiaire', although especially with respect to the scenario that we would have after the accession of the Union to the ECHR. 
creative work done by the ECJ can be justified merely on Article 19 TEU.61 Actually, the general principles in question still have a function that is anything but superfluous within the EU legal system and their role should be emphasized and not, on the contrary, marginalized, even when - as we shall see - they intervene only in an alternative role. ${ }^{62}$

\subsection{THE CONVENTION FOR THE PROTECTION OF HUMAN RIGHTS AND FUNDAMENTAL FREEDOMS AS A SOURCE OF INSPIRATION FOR THE DEVELOPMENT OF GENERAL PRINCIPLES OF LAW CONCERNING FUNDAMENTAL RIGHTS}

As previously seen, Article 6(3) TEU (and the former Article F.2 TEU in the version resulting from the Maastricht Treaty) identifies two sources of inspiration, both external to the EU legal order, for the development of general principles of law designed to protect the fundamental rights of the individual.

The first of these sources is the ECHR; the second source is represented by the constitutional traditions common to the Member States. ${ }^{63}$ It was this latter source that served as the reference base for the oldest decisions of the ECJ regarding the enforcement of such rights in what was then the European Economic Community. This is because, at the

61 Jean-Claude Bonichot, 'Des rayons et des ombres: les paradoxes de l'article $6 \mathrm{du}$ Traité sur l'Union européenne' in La conscience des droits. Mélanges en l'honneur de Jean-Paul Costa (Dalloz 2011) 49, 64. Similarly, stating that Article 6(3) TEU is not necessary and almost dangerous, see Christoph Grabenwarter, Katharina Pabel, 'Article 6 [Fundamental Rights - The Charter and the ECHR]' in Hermann-Josef Blanke, Stelio Mangiameli (eds), The Treaty on European Union (TEU): A Commentary (Springer 2013) 287, 333. Luigi Daniele questions the advisability of keeping Article 6(3) TEU ('La protezione dei diritti fondamentali nell'Unione europea dopo il trattato di Lisbona: un quadro d'insieme' (2009) 14 DUE 645, 650).

62 See ch 4. In favour of keeping Article 6(3) TEU, especially in its integrating role, see Weitzel (n 16) 229, stressing how this 'n'est pas anodine et relève [...] du souci des Etats membres de ne pas remettre en question l'acquis jurisprudentiel et les potentialités' of the general principles of law. Most recently, see Bucura C Mihaescu Evans, "Gaps" in Protection Stemming from the Coexistence of Fundamental Rights' Sources in the EU Legal Order' (2016) 52 $C D E 141$.

63 Case 29/69 Stauder ECLI:EU:C:1969:57; Case 11/70 Internationale Handelsgesellschaft mbH ECLI:EU:C:1970:114. 
time (at the end of the 1960s and the beginning of the 1970s), not all of the six Member States of the Community were contracting parties of the ECHR. For this same reason, in the first decisions affirming, also on the part of the Community, the obligation to protect fundamental rights guaranteed (in particular) by the ECHR, a broader and generic wording is used that does not make exclusive and express reference to that source. In the well known Nold case of 1974, the ECJ, after mentioning (specifically) the ECHR as an international source of law protecting the right to private property, notes in general that useful elements to ensure the protection of fundamental rights in the Community legal order can be inferred from 'international treaties for the protection of human rights on which the Member States have collaborated or of which they are signatories'.64

In 1975 the ECJ delivered its first decision 'introducing' into the Community legal system a general principle of law inferred exclusively from the ECHR, which had by then been ratified, as the Court notes, by all of the (at that time) nine States of the Community. ${ }^{65}$ Starting from this date, and while there continued to be decisions using other international conventions as a source of inspiration, ${ }^{66}$ it became increasingly more frequent to use only this Convention as a reference basis for ascertaining fundamental rights. ${ }^{67}$ Indeed the ECJ itself repeatedly recognized that, in comparison with other international conventions, the ECHR acquires a 'special significance' for EU law. ${ }^{68}$

64 Case 4/73 ECLI:EU:C:1974:51, para 13. Similarly see, e.g. Case 44/79 Hauer ECLI:EU:C:1979:290, para 15, and Case 136/79 National Panasonic $v$ Commission ECLI:EU:C:1980:169, para 18.

65 Case 36/75 Rutili ECLI:EU:C:1975:137, para 32. The last Member State to ratify the ECHR was France in 1974.

66 See this ch 1.6.

67 For an analysis of the jurisprudence of the ECJ that - before the entry into force of the Lisbon Treaty - uses the ECHR as a general principle of law, see Antonio Bultrini, La pluralità dei meccanismi di tutela dei diritti dell'uomo in Europa (Giappichelli 2004) 13; Cezary Mik, 'Significance of the ECHR Provisions for the Protection of Fundamental Rights as General Principles of the EU Law' in Jan Barcz (ed.), Fundamental Rights Protection in the EU (CH Beck 2009) 202; John L Murray, 'The Influence of the European Convention on Fundamental Rights on Community Law' (2011) 34 Fordham Int'l L J 1388; Delphine Dero-Bugny, Les rapports entre la Cour de justice de l'Union européenne et la Cour européenne des droits de l'homme (Bruylant 2015) $25 \mathrm{ff}$. 68 See, e.g. Case 222/84 Johnston ECLI:EU:C:1986:206, para 18; Case C-274/99 P Connolly v Commission ECLI:EU:C:2001:127, para 37; Case C-94/00 Roquette Frères ECLI:EU:C:2002:603, para 25; Case C-112/00, Schmidberger ECLI:EU:C:2003:333, para 71. 
Instead, reference in the decisions of the ECJ to the jurisprudence of the Strasbourg Court clearly interpreting the ECHR required more time. The Advocates General started making such references in their Opinions only at the end of the $1980 \mathrm{~s},{ }^{69}$ and the first decision of the ECJ that 'avails itself' of such jurisprudence is dated 1996.70 Starting from this date, the use of the Strasbourg jurisprudence to ensure the protection of a fundamental right as a general principle has become increasingly more frequent. As we shall see in greater detail below, ${ }^{71}$ we are witnessing - at least since the beginning of the twenty-first century - a mutual influence of the jurisprudence of the two Courts, in which even the Strasbourg Court 'takes as a starting point' the decisions of the ECJ protecting the fundamental rights of the individual.

\subsection{THE RELEVANCE OF THE 'CONSTITUTIONAL TRADITIONS COMMON TO THE MEMBER STATES' FOR THE ASSESSMENT OF GENERAL PRINCIPLES OF LAW CONCERNING FUNDAMENTAL RIGHTS}

The second source mentioned in Article 6(3) TEU as a reference basis for the drawing up of general principles of law consists of the constitutional traditions common to the Member States. This even though, as mentioned above, that source of inspiration had already been used by the ECJ to guarantee the protection of the fundamental rights of the individual also in the Community legal system before resorting to (other international sources and to) the ECHR. ${ }^{72}$

69 See, e.g. Case 236/86 Bergemann ECLI:EU:C:1988:443, Opinion of AG Lenz, para 27; Case 374/87 Orkem v Commission ECLI:EU:C:1989:387, Opinion of AG Darmon, paras 131-145. Moreover, reference is made to the fact that, at the end of 1974 (the year before which the ECJ for the first time, as mentioned, referred only to the ECHR to define a general principle of law) the ECtHR delivered only 19 decisions (cf Bultrini (n 67) 19).

70 Case C-13/94 P v S and Cornwall County Council ECLI:EU:C:1996:170, para 16. Instead, for the first decision that refers to the ECtHR see Joined Cases 46/87 and 227/88 Hoechst $v$ Commission ECLI:EU:C:1989:337, para 18. For the fact that the ECJ 'attaches the greatest importance to the case-law of' the ECtHR see Case C-94/00 Roquette Frères SA ECLI:EU:C:2002:603, Opinion of AG Misho, para 33.

71 Ch 22.2 .

72 See this ch 1.4. 
The interpretative work of the ECJ is characterized by a high degree of creativity. Despite the constant reference to the 'common' constitutional traditions to the Member States, the analysis of the Luxembourg Judge about the 'an' and the 'quantum' regarding the protection of the fundamental right in question from time to time in the various Member States is in fact only slightly comparative, or in any case more creative than really comparative. ${ }^{73}$ The greater the number of the EU Member States is, the less comparative the analysis becomes. ${ }^{74}$ Therefore, not infrequently we find cases in which the ECJ ascertains the existence of a fundamental right to be enforced within the Union as a general principle of law even without identifying a 'lowest common denominator' in the level of protection of a certain fundamental right in the legislations of the Member States. Instead, it is easier to find in the Opinions of the Advocates General a detailed analysis of the constitutional specificities if not of all of the Member States, at least of a substantial number of these with respect to the total. ${ }^{75}$

Among the most famous cases in which the ECJ declared that it inferred the existence of a general principle from the common constitutional traditions are the Berlusconi and Others and the Mangold ${ }^{76}$

73 Oreste Pollicino, 'Corte di giustizia e giudici nazionali: il moto "ascendente", ovverosia l'incidenza delle "tradizioni costituzionali comuni" nella tutela apprestata ai diritti dalla Corte dell'Unione' <http://www.giurcost.org/studi/ Pollicino2.pdf>, 20 April 2015, also for further bibliographical references.

74 Although, in light of such increase, the number of the legislations examined to verify the existence of a 'common' value or principle should be higher compared with what happened in a Community composed of a lower number of States.

75 Koen Lenaerts, Kathalin Gutman, 'The Comparative Law Method and the Court of Justice of the European Union. Interlocking Legal Orders Revisited' in Mads Andenas, Duncan Fairgrieve (eds), Courts and Comparative Law (OUP 2015) 141, 145 ff. See also Koen Lenaerts, 'The European Court of Justice and the Comparative Law Method' (2017) 25 European Review of Private Law 297, $307 \mathrm{ff}$.

76 See, respectively, Joined Cases C-387/02, C-391/02 and C-403/02 ECLI: EU:C:2005:270, paras 66-69, and Case C-144/04 ECLI:EU:C:2005:709, paras 74-75. For older cases, however offering a brief outline of the general principle, whose common existence in the Member States had actually been denied by the Advocates General see, e.g. Case 17/74 Transocean Marine Paint Association v Commission ECLI:EU:C:1974:106, para 15, and Case 110/75 Mills v EIB ECLI:EU:C:1976:152, 1621. For a more detailed assessment of the common constitutional traditions of the Member States, although without formally outlining a general principle of law, see Joined Cases C-122/99 P and C-125/99 P D and Sweden v Council ECLI:EU:C:2001:304, paras 34-36, and Case C-550/07 P 
decisions, although an actual comparative assessment of the relevant national laws was not carried out, and respectively either the right or the principle in question was provided for only in a reduced number of Member States. In the first case, indeed, the principle of retroactivity of the more lenient criminal law (today also explicitly codified in Article 49(1) of the Charter) is established as a general principle of law - a principle that was not expressly foreseen at a constitutional level in the legal system of the referring judge (Italy). In that State, in fact, the principle in question is provided for only in the criminal code (in Article 2(2)) and not in the Constitution, which expressively sets forth (in Article $25(2))$ only the principle of non-retroactivity in malam partem. ${ }^{77}$

\subsection{THE OTHER MEANS FOR THE COURT OF JUSTICE TO ELABORATE GENERAL PRINCIPLES OF LAW: (I) THE INFLUENCE OF SOURCES OF INTERNATIONAL LAW; (II) THE INDUCTIVE PROCESS FROM OTHER PROVISIONS OF THE EU LAW; (III) SOLICITATION BY OTHER INSTITUTIONS, BODIES, OFFICES AND AGENCIES OF THE UNION}

As pointed out above, Article 6(3) TEU mentions only two sources of inspiration, external to the EU legal system, to which the EU Judges may turn for the ascertainment and subsequent protection of the fundamental rights of the individual. It has also been noted that the latter provision, introduced with the Maastricht Treaty, codifies the jurisprudence of the ECJ developed since the Stauder decision in 1969; and that such jurisprudence, especially before all of the Member States adhered to the ECHR, used the 'international treaties for the protection of human rights on which the Member States have collaborated or of which they are signatories' as a reference basis for the identification of general principles of law.

Akzo Nobel Chemicals and Akcros Chemicals v Commission ECLI:EU:C: 2010:512, paras 69-76.

77 Also the representation proposed by AG Kokott in her Opinion in the Berlusconi and Others case does not appear to be detailed. In fact, although stating that the principle in question is recognized by almost all Member States (at that time 25), the AG only makes reference to the relevant provisions of the Italian and the German criminal codes (para 156). 
Therefore, the codification realized with the Maastricht Treaty might appear simplistic, since the provision makes reference only to the ECHR and not also, more generally, to other international conventions protecting fundamental rights. Of course, as already mentioned, the ECHR has always played a major role in the ECJ jurisprudence aimed at guaranteeing the enforcement of those rights. However, despite being the main international source of inspiration for the EU Judges, this Convention is not the only one that has been used in the development of general principles of law. Among the decisions that confer relevance to instruments of international law in this regard we may recall, in particular, besides the already mentioned Nold decision, referencing the Universal Declaration of Human Rights, the Defrenne decision, referencing the OIL Convention No. 111 regarding non-discrimination among men and women in the workplace; the Blaizot decision, referencing the European Social Charter; the Orkem $v$ Commission decision, referencing the International Covenant of the United Nations on Civil and Political Rights; the decision European Parliament v Council of 2006 (the first where the Charter of Fundamental Rights is also mentioned) where the Convention on the Rights of the Child of 1989 is especially relevant; the Dynamic Medien decision in which the last mentioned Convention is also relevant; and the Bressol and Others decision referencing the Covenant on Economic, Social and Cultural Rights. ${ }^{78}$ Numerous are the decisions referring to the 1951 Geneva Convention relating to the status of the refugees. ${ }^{79}$

Despite certain doubts raised on the topic in scholarly works, ${ }^{80}$ it seems correct to assume that, today as in the past, the list of the sources of inspiration of the general principles of law included in Article 6(3) TEU is not complete. Therefore, even in the absence of an explicit reference to other international sources in the provision in question, also other international instruments, different from the ECHR, may be

78 See, respectively, Case 4/73 ECLI:EU:C:1974:51; Case 43/75 ECLI:EU: C:1976:56; Case 24/86 ECLI:EU:C:1988:43; Case 374/87 ECLI:EU:C:1989:387; Case C-540/03 ECLI:EU:C:2006:429; Case C-244/06 ECLI:EU:C:2008:85; Case C-73/08 ECLI:EU:C:2010:181. On the same topic, although dated, see Allan Rosas, 'The European Union and International Human Rights Instruments' in Vincent Kronenberger (ed.), The European Union and the International Legal Order: Discord or Harmony (TMC Asser Press 2001) 1691.

79 See, e.g. Joined Cases C-95/99 to C-98/99 and C-180/99, Khalil and Others ECLI:EU:C:2001:532, Case C-337/07, Altun ECLI:EU:C:2008:744.

80 In the sense that the wording of Article 6(3) TEU seems to prohibit the ECJ from using sources of international law different from the ECHR in order to ascertain the existence of new fundamental rights see, e.g. Sudre (n 4) 151. 
legitimately used - even with Article 6(3) in its post-Lisbon wording - by the ECJ to ascertain the existence of a general principle of law for the protection of a fundamental right in the EU legal order. ${ }^{81}$

Moreover, the final arbiter of this provision is the EU Judge, which may consider it as a legal parameter to assess general principles regarding fundamental rights also through sources of inspiration not explicitly mentioned in it. In any event, to strengthen this reading we might also mention Article 19 TEU which, as indicated above, would be sufficient in itself to justify the interpretative and creative work of the Luxembourg Judge in identifying the general principles of law. ${ }^{82}$

In any case, the interpretation here proposed of Article 6(3) TEU, besides being in line with the ECJ jurisprudence, is also coherent with the Charter's provisions, which, reaffirming the general principles of law, use as their own sources of inspiration also international agreements different from the ECHR. In this respect, besides the Preamble to the Charter, the Explanations relating to it are relevant, in particular sub Article 1 (referencing the Universal Declaration of Human Rights), sub Article 3 (referencing the Convention on Human Rights and Biomedicine adopted within the European Council), sub Article 14 (referencing the Community Charter for the Social Fundamental Rights of Workers and the European Social Charter), sub Article 18 (referencing the Geneva Convention relating to the status of refugees), sub Article 19 (referencing the International Covenant on Civil and Political Rights), sub Article 23 (referencing the Community Charter of the Social Fundamental Rights of Workers), sub Article 24 (referencing the Convention on the Rights of the Child of 1989), sub Article 25 (referencing the European Social Charter),

81 In favour of the solution proposed in the text see Girolamo Strozzi, 'Il sistema integrato di tutela dei diritti fondamentali dopo Lisbona: attualità e prospettive' (2011) DUE 837, 841; Clemens Ladenburger, 'Institutional Report. Session on "Protection of Fundamental Rights post-Lisbon - The Interaction between the Charter of Fundamental Rights, the European Convention of Human Rights and National Constitution" < <ttp://www.fide2012.eu/index.php?doc_id= 88> 4; Allan Rosas, 'The Charter and Universal Human Rights Instruments' in Peers, Hervey, Kenner, Ward (eds) (n 25) 1685, also with an analysis of the relevant jurisprudence. Gráinne de Búrca criticizes the scarce reference to international instruments for protection of human rights and the relevant practice, advocating their increased use ("After the EU Charter of Fundamental Rights: The Court of Justice as a Human Rights Adjudicator?' (2013) 20 MJ 168).

82 See the legal literature quoted at n 61 . 
sub Article 26 (referencing the European Social Charter and the Community Charter of the Social Fundamental Rights of Workers) and sub Articles 27-35 (referencing the latter two mentioned instruments). ${ }^{83}$

We could therefore wonder whether such a procedure may be used only with reference to international agreements ratified by all the Member States. The answer seems to be negative, admitting the statement of a new general principle also on the basis of a convention to which only some Member States are parties. The ECJ has already demonstrated, as previously seen, the possibility of using the ECHR as a source of inspiration even before all of the Member States had adhered to it. ${ }^{84}$ Also, the creative activity that the EU Judge performs with respect to the 'common' constitutional traditions would appear to argue in favour of the possibility of attesting the existence of a general principle by inferring it from an international convention to which not all Member States are bound. Again, even the Charter and its Explanations attest that international conventions to which not all of the Member States are parties are a source of inspiration of certain provisions of the written catalogue of rights. ${ }^{85}$

Also, but not only, on the basis of what is provided for in the above-mentioned Article 19 TEU, other means of determining fundamental rights of the individual through the interpretative and creative work of the ECJ appear to be identifiable. In order to contribute to the process of European integration, the Luxembourg Judge could thus, for example, identify new fundamental rights as general principles through a process of inference from written provisions of EU law, whether primary and/or secondary law. In this case, the development of the fundamental

83 On how the Charter should be interpreted taking into consideration the relevant international sources (even different from the ECHR), and their interpretation by the competent bodies, see Giorgio Gaja, 'The Charter of Fundamental Rights in the Context of International Instruments for the Protection of Human Rights' (2016) 1 European Papers 791.

84 The same occurred, e.g. with respect to the European Social Charter: see Case 24/86 Blaizot ECLI:EU:C:1988:43.

85 Reference is made, e.g. to the European Social Charter (as of 31 August 2017, Estonia and Lithuania have not signed the Charter, while Romania and Slovenia have yet to ratify it), to the Convention on Human Rights and Biomedicine (as of 31 August 2017, Austria, Belgium, Germany, Ireland, Malta and the UK are not signatories to the Convention, while Italy, Luxembourg, Netherlands, Poland and Sweden still have to complete the ratification process), or to Protocol No. 7 to the ECHR, whose Article 4 sets forth the ne bis in idem principle (as of 31 August 2017, the UK has not signed the Protocol, while Germany and the Netherlands have yet to ratify it). 
right would occur not through the more traditional mechanism of deduction from external sources, but by way of induction, abstraction and generalization, starting from provisions already included in the EU legal system, thereby underlining their transversal nature. ${ }^{86}$

Again, new fundamental rights as general principles could be identified by the ECJ upon solicitation of other institutions and of EU bodies, offices and agencies, constantly stressing the need, even through acts of soft law, to ensure the protection of a certain (new) fundamental right. Furthermore, a source of inspiration for new general principles could be the practice of institutions, bodies, offices and agencies in their 'daily work' relating to the protection of certain rights. ${ }^{87}$

Finally, the analysis of the practice of the EU institutions, bodies, offices and agencies regarding the promotion of the protection of fundamental rights, sometimes leading to an actual extension of their scope of activity, would be of considerable interest but cannot be fully developed here. Apart from the practice of the European Commission ${ }^{88}$ and of the Parliament, certainly better known, or even, for example, of the Agency for Fundamental Rights, reference is made in particular to the role of the so-called Group 29, created as a consulting and independent body on the basis of Article 29 of 95/46/EC Directive. ${ }^{89}$ This Group, after the decision of the ECJ declaring the invalidity of Directive 2006/24/CE,90 issued a 'statement on the ruling of the Court of Justice of the European Union which invalidates the Data Retention Directive'91 regarding the consequences of that decision on the domestic laws adopted for its implementation. Further, after the decision imposing the

86 On how to define a general principle of law see this ch 1.3.

87 For examples of development of new general principles concerning fundamental rights through the mentioned means see ch 44.5 .

88 See the strategy for an effective implementation of the Charter of Fundamental Rights, COM (2010) 573 final.

89 Directive 95/46/EC of the European Parliament and of the Council of 24 October 1995 on the protection of individuals with regard to the processing of personal data and on the free movement of such data [1995] OJ L281/31.

90 Joined Cases C-293/12 and C-594/12 Digital Rights Ireland and Seitlinger and Others ECLI:EU:C:2014:238. See Directive of the European Parliament and of the Council of the 15 May 2006 on the retention of data generated or processed in connection with the provision of publicly available electronic communications services or of public communications networks and amending Directive 2002/58/EC [2006] OJ L105/54.

91 See <http://ec.europa.eu/justice/data-protection/article-29/documentation/ opinion-recommendation/files/2014/wp220_en.pdf>. 
de-indexation of personal data, ${ }^{92}$ it developed guidelines ${ }^{93}$ for all of the national authorities in charge of the protection of such rights. By doing so it de facto allowed the latter, while managing complaints regarding the right to de-indexation, to feed with practical content said right as established by the Court. Reference may also be made to the practice of the European Central Bank of disclosing the drafts of the sessions of the Executive Board to ensure more transparency in its activities although in accordance with Article 15(3) TFEU - it is strictly required to comply with such principle only in performing its administrative functions. ${ }^{94}$

\subsection{ARTICLE 6(2) TEU: THE PROVISION OF THE ACCESSION OF THE EUROPEAN UNION TO THE ECHR}

Article 6(2) TEU was included in the Treaties by the Lisbon reform and constitutes the legal basis for the Union's accession to the ECHR. This provision, along with the conferral of binding value to the Charter, represents 'a major step forward towards a stronger and more coherent system of fundamental rights protection', 95 thus confirming the centrality that the protection of such rights has acquired in the EU legal system. Today the ECHR becomes relevant in this legal system (at least formally, as we shall see) on the basis of all three paragraphs of Article 6 TEU: they confer upon this source a different 'consistency' within the European Union based on the specific manner (potential or actual, direct or indirect) in which it could (under paragraph 3), should (under paragraph 1 read together with Article 52(3) CFR) or shall (under paragraph 2) enter into it.

The first formalization of the idea of the accession of the, at the time, European Economic Community to the ECHR, dates back to 1979. In fact, in April of that year the Commission presented the 'Memorandum on the accession of the European Communities to the Convention for the

\footnotetext{
92 Case C-131/12, Google Spain ECLI:EU:C:2014:317.

93 See <http://ec.europa.eu/justice/data-protection/article-29/documentation/ opinion-recommendation/files/2014/wp225_en.pdf>.

94 Mariagrazia Buonanno, 'BCE: un passo verso la trasparenza delle scelte di politica monetaria' <http://rivista.eurojus.it/>, 26 February 2015.

95 Jörg Polakiewicz, 'The EU's Accession to the European Convention on Human Rights - A Matter of Coherence and Consistency' in Morano-Foadi, Vickers (eds) (n 26) xvii.
} 
Protection of Human rights and Fundamental Freedoms', ${ }^{96}$ highlighting the need for an external control regarding the protection of fundamental rights, also in order to insure greater coherency between the jurisprudence of the ECJ and that of the ECtHR. The institution, although aware of the possible objections to its proposal, stated that the 'best way' to respond to the need to strengthen the protection of fundamental rights in the Community legal system was the accession to the ECHR.

In truth, a first proposal of accession had already been developed by the Comité d'etudes pour la constitution européenne, created in 1952 by the members of the Mouvement européen, a political group founded in 1948 for the promotion of community integration. ${ }^{97}$ This Committee collaborated with the assembly instituted ad hoc for the creation of a European Political Community, a project in parallel to the one aimed at the elaboration of the Treaty establishing the European Defense Community (EDC). 98

Both projects having failed, the idea of the accession was proposed again in the so-called Spinelli Draft of 1984, ${ }^{99}$ which stated (in Article 4) that the Union to be created would have had, within five years of the entry into force of the Treaty establishing the European Union, to: (i) adopt its own catalogue of rights; and (ii) decide whether to accede to the ECHR.

When this project fell through, the matter of accession was addressed by the Council on the basis of the mentioned Memorandum of 1979, in April 1986. The Council voted by majority in favour of accession and, in light of such consent, on the 19 November 1990, on the fortieth

96 Bulletin EC of the 4 April 1979, Supplement No. 2/79. For a detailed analysis of this Memorandum and a broad historical recreation of all stages of the (prospected) accession, including the works (of the various Groups) that have led to the preparation of the draft agreement submitted to the scrutiny of the ECJ in Opinion 2/13 see Ilaria Anrò, L'adesione dell'Unione europea alla CEDU. L'evoluzione dei sistemi di tutela dei diritti fondamentali in Europa (Giuffrè 2015).

97 Gráinne de Búrca, 'The Road Not Taken: The EU as a Global Human Rights Actor' (2011) 105 AJIL 649.

98 See Mouvement européen, projet de statut de la communauté politique européenne: travaux préparatoires, 1952, 18, pt 207.

99 The Treaty establishing the European Union drafted by the Committee for Institutional Affairs of the European Parliament, assisted by a group of legal experts composed of Professors Francesco Capotorti, Meinhardt Hilf, Francis Jacobs and Jean-Paul Jacqué. The Assembly approved the definitive text ([1984] OJ C77/33) by a resolution of the 14 February 1984, approved with 237 votes in favour, 31 against and 43 abstentions. 
anniversary of the signature of the ECHR, the Commission submitted to the Councilioo a communication containing a formal proposal of accession and the request of authorization to conduct negotiations. Once the negotiations started, in November 1993 the Council, meeting in its Justice configuration, formally decided to avail itself of the procedure under former Article 228(6) TEC (today Article 218(11) TFEU), requesting the ECJ to deliver an Opinion on the compatibility of the draft agreement providing the accession of the, at the time, European Community to the ECHR with the Treaties. The request was filed in April 1994 and the Court delivered its Opinion on the 28 March 1996, substantially blocking the possibility of accession. ${ }^{101}$

First of all, with reference to the admissibility of the request for the Opinion, and therefore to the possibility of ruling on the compatibility of the draft accession agreement with the Treaties, the Luxembourg Judge stated that it did not have sufficient elements to respond in detail, since no clarification had been provided regarding the mechanisms of judicial review (present and future) of the ECHR system with which the Community would have had to comply. ${ }^{102}$

With reference to the competence of the Community to accede, the ECJ stated that no provision of the Treaties conferred to the institutions the authority to approve general laws regarding human rights or to accede

100 Commission Communication on Community accession to the ECHR and some of its Protocols, SEC(90) 2087 final.

101 Opinion 2/94 Adhésion de la Communauté à CEDH ECLI:EU: C:1996:140. See Olivier De Schutter, Yves Lejeune, 'L'adhésion de la Communauté à la Convention européenne des droits de l'homme. A propos de l'avis 2/94 de la Cour de Justice des Communautés' (1996) 32 C D E 817; Giorgio Gaja, 'Opinion 2/94, Accession by the Community to the European Convention for the Protection of Human Rights and Fundamental Freedoms, given on 28 March 1996, not yet reported' (1996) 33 CML Rev 973; Siofra O’Leary, 'Current Topic: Accession by the European Community to the European Convention on Human Rights - The Opinion of the ECJ' (1996) E H R L R 362; Lucia Serena Rossi, 'Il parere 2/94 sull'adesione della Comunità europea alla Convenzione europea dei diritti dell'uomo' (1996) 1 DUE 839; Patrick Wachsmann, 'L'avis 2/94 de la Cour de justice relatif à l'adhésion de la Communauté européenne à la Convention de sauvegarde des droits de l'homme et des libertés fondamentales' (1996) RTDE 467; Antonio Bultrini, 'La questione dell'adesione della Comunità europea alla Convenzione europea dei diritti dell'uomo di fronte alla Corte di giustizia' (1997) 33 Rivista di diritto internazionale privato e processuale 97; Ákos G Tóth, 'The European Union and Human Rights: The Way Forward' (1997) 34 CML Rev 491.

102 Ibid., paras 20-21. 
to international conventions in that field. ${ }^{103}$ Differently from what was held by the Commission in the Memorandum of 1979, not even the former Article 235 TEC (today Article 352 TFEU) could constitute an adequate legal basis for this purpose, since it could not allow an expansion of the powers of the European Community with subsequent interventions that would have entailed a material amendment to the Treaty, without following the procedure which it provided for that purpose. ${ }^{104}$ The Court thus noticed the indisputable relevance of fundamental rights in the Community legal system and recalled how they constituted a parameter of legality (also) for the Community acts. ${ }^{105}$ However, the Court concluded that the accession, by entailing the insertion of the Community in a separate international institutional system, as well as the integration of all of the ECHR's provisions in the Community legal system, would have necessarily caused a substantial change in the Community system for the protection of fundamental rights. 106 The institutional implications of such a change would have been, in the opinion of the Court, of constitutional relevance, falling outside the scope of Article 235 TEC, and achievable only through the procedure for the revision of the Treaties.107 Therefore, the Court concluded that 'as Community law now stands, the Community has no competence to accede to the Convention'. 108

The solution identified in the Opinion as the only one possible to concretely pursue the accession had already been adopted in the Constitutional Treaty (Article I-9(2)) and was then reproposed by the Intergovernmental Conference that had drawn up the Lisbon Treaty. In fact, the latter, as mentioned above, amended Article 6(2) TEU (the content of which was transferred to the following paragraph 3), creating an ad hoc legal basis to legitimize the Union for acceding to the ECHR. It also specifies that the accession 'shall not affect the Union's competences as defined in the Treaties'.

Furthermore, Protocol No. 8 annexed to the TEU and the TFEU relating to Article 6(2) of the TEU on the accession of the Union to the ECHR, raised a series of conditions to be respected in order to ensure the validity of the accession agreement. In particular, Article 1 of the Protocol sets forth that:

\footnotetext{
103 Ibid., para 27.

104 Ibid., paras 30 and 35.

105 Ibid., paras 32-34.

106 Ibid., para 34.

107 Ibid., para 35.

108 Ibid., para 36.
} 
The agreement relating to the accession of the Union to the European Convention on the Protection of Human Rights and Fundamental Freedoms (hereinafter referred to as the 'European Convention') provided for in Article 6(2) of the Treaty on European Union shall make provision for preserving the specific characteristics of the Union and Union law, in particular with regard to: (a) the specific arrangements for the Union's possible participation in the controlling bodies of the European Convention; (b) the mechanisms necessary to ensure that proceedings by non-Member States and individual applications are correctly addressed to Member States and/or the Union as appropriate. ${ }^{109}$

The following Article 2 sets forth that:

The agreement referred to in Article 1 shall ensure that accession of the Union shall not affect the competences of the Union or the powers of its institutions. It shall ensure that nothing therein affects the situation of Member States in relation to the European Convention, in particular in relation to the Protocols thereto, measures taken by Member States derogating from the European Convention in accordance with Article 15 thereof and reservations to the European Convention made by Member States in accordance with Article 57 thereof.

Lastly, Article 3 provides that: 'Nothing in the agreement referred to in Article 1 shall affect Article 344 of the Treaty on the Functioning of the European Union'.

These conditions are incorrectly deemed not binding by respected scholars, according to whom

En réalité soit le Protocole n. 8 soit la dernière partie de l'art. 6, par. 2 n'ont pas une grande valeur du point de vue juridique, étant donné que l'accord d'adhésion devra être ratifié par tous les Etats membres de l'UE, ainsi que par les Membres du Conseil de l'Europe, et donc il pourra parfaitement déroger aux règles que l'on vient de citer. ${ }^{110}$

This approach does not seem to take into account either the necessary approval by the European Parliament of the draft accession agreement under Article 218(6)(a)(ii) TFEU, or the power of the ECJ to render Opinions regarding the compatibility of the agreement envisaged with the Treaties under Article 218(11) TFEU. Failure to comply with the above-mentioned conditions would most probably have been detected by

\footnotetext{
109 Emphasis added.

110 Benedetto Conforti, 'L'adhésion de l'Union Européenne à la Convention Européenne des Droits de l'Homme' in Luc Weitzel (ed.), (n 16) 21 (emphasis added).
} 
the European Parliament when approving the agreement and censored by the Court if asked to deliver an Opinion (as indeed happened).

With respect to the ECHR system, an intervention aimed at amending Article 59 of the Convention was necessary in order to allow the Union to accede to it: in the past the only Contracting Parties could be the States, while today paragraph 2 of that Article sets forth that: 'The European Union may accede to this Convention'. This amendment was introduced by Article 17 of the additional Protocol No. 14, signed in Strasbourg on the 13 May 2004 and entered into force on the 1 June 2010, following the ratification by all the States members of the Council of Europe. ${ }^{111}$

\subsection{OPINION 2/13 OF THE COURT OF JUSTICE AND THE CURRENT RELEVANCE OF THE ECHR IN THE LEGAL SYSTEMS OF THE EUROPEAN UNION AND OF THE MEMBER STATES}

In light of the new legal basis included in Article 6(2) TEU and of the amendment of Article 59 ECHR, the negotiations for drafting the accession agreement started in March 2010 and ended in Spring 2013. ${ }^{112}$ The accession envisaged in the draft agreement does not cover, however, the Convention entered into force in 1950 and all of the additional Protocols, but only the 1950 text along with the first and sixth additional Protocols, those being the only texts ratified by all EU Member States. This is - as clarified in Article 218 TFEU which sets forth the procedure that the Union must follow for entering into the said agreement - a sui generis agreement. In fact, it requires the unanimous vote of the Council, the approval of the European Parliament and also, in order to enter into force, the approval of all EU Member States according

111 See further Stéfanie Lagoutte, 'Le Protocol 14 à la Convention europénne des droits de l'homme: une assurance de la pérennité du système européen de protection des droits de l'homme?' (2005) 41 C D E 127; Lucius Caflisch, 'The Reform of the European Court of Human Rights: Protocol no. 14 and beyond' (2006) H R L Rev 403.

112 See the draft agreement on the accession of the European Union to the ECHR, finalized on the 5 April 2013, in the version presented on the 10 June 2013 in Strasbourg by the negotiators to the Steering Committee for Human Rights and the final report to the Steering Committee for Human Rights (Rapport final au CDDH), Doc. No. 47+1(2013)008 rev2, <http://www.coe.int/t/dghl/ standardsetting/hrpolicy/Accession/Meeting_reports/47_1(2013)008rev2_EN.pdf>. 
to their respective constitutional laws (in addition to the ratification by all the States of the Council of Europe).

The ECJ was once again requested to deliver an Opinion under Article 218(11) TFEU. In this case the request was brought by the Commission in July 2013.

In this second Opinion the Luxembourg Judges noted the substantial incompatibility of the draft agreement on the accession with the Treaties (better said, with Article 6(2) TEU and with the mentioned Protocol No. $8),{ }^{113}$ blocking once again the process of accession of the European

113 See the above-mentioned Opinion 2/13 Adhésion de l'Union à la CEDH ECLI:EU:C:2014:2454. Above and beyond the numerous comments appeared on different blogs in the days immediately following its publication (for a first list see <http://www.eurojus.it/il-parere-213-della-corte-di-giustizia-sulladesionedellunione-europea-alla-cedu-follow-up-sulle-reazioni-della-dottrina/>), for an in-depth analysis of the Opinion see Jean-Paul Jacqué, 'CJUE - CEDH: 2-0' (2014) RTDE 823; id., 'Pride and/or Prejudice? Les lectures possibles de l'avis 2/13 de la Cour de Justice' (2015) 51 C D E 19; Anrò (n 96) 273; Maria Berger, Clara Rauchegger, 'Opinion 2/13: Multiple Obstacles to the Accession of the EU to the ECHR' (2015) 15 European Yearbook on Human Rights 61; Leonard FM Besselink, Monica Claes, Jan Herman Reestman, 'A Constitutional Moment: Acceding to the ECHR (or not)' (2015) 11 EuConst 2; Bruno De Witte, Šejla Imamović, 'Opinion 2/13 on Accession to the ECHR: Defending the EU Legal Order against a Foreign Human Rights Court' (2015) 40 E L Rev 683; Edouard Dubout, 'Une question de confiance: nature juridique de l'Union européenne et adhésion à la Convention européenne des droit de l'homme' (2015) 51 C D E 73; Enzo Cannizzaro, 'Unitarietà e frammentazione delle competenze nei rapporti fra l'ordinamento dell'Unione e il sistema della Convenzione europea: in margine al parere della Corte di giustizia 2/2013' (2015) 20 DUE 623; Editorial Comment, 'The EU's Accession to ECHR - a "NO" from ECJ!' (2015) 52 CML Rev 1; Piet Eeckhout, 'Opinion 2/13 on EU Accession to the ECHR and Judicial Dialogue Autonomy or Autarky?' <http://jeanmonnetprogram.org/paper/opinion-213-oneu-accession-to-the-echr-and-judicial-dialogue-autonomy-or-autarky/>, 1/2015; Daniel Halberstam, “'It's the Autonomy, Stupid!”. A Modest Defense of Opinion 2/13 on EU Accession to the ECHR, and the Way Forward' (2015) 16 German Law Journal 105; Louise Halleskov Storgaard, 'EU Law Autonomy versus European Fundamental Rights Protection - On Opinion 2/13 on EU Accession to the ECHR' (2015) $15 H R L$ Rev 485; Henry Labayle, Frédéric Sudre, 'L'avis 2/13 de la Cour de justice sur l'adhésion de l'Union européenne à la Convention européenne des droits de l'homme. Pavane pour une adhésion défunte?' (2015) 31 RFDA 3; Tobias Lock, 'The Future of the European Union's Accession to the European Convention on Human Rights after Opinion 2/13: Is It still Possible and Is It still Desirable?' (2015) 11 EuConst 239; Ingolf Pernice, 'L'adhésion de l'Union européenne à la Convention européenne des droits de l'homme est suspendue' (2015) 51 C D E 47; Denis Simon, 'Deuxième (o second et dernier?) coup d'arrêt à l'adhésion de l'Union à la CEDH: étrange avis 2/13' (2015) 
Union to the ECHR. The profiles of incompatibility of the agreement envisaged identified by the ECJ number seven, essentially stating that, as drafted, the agreement would constitute a threat to the autonomy (and the supremacy) of the EU legal system and of the ECJ itself, whose work might have been subject to review (and could have potentially been censored) by a judicial body external to the system, i.e. the ECtHR. The fundamental rights, which the Union undoubtedly respects, shall be interpreted, in the opinion of the ECJ, in the context of the EU structure and in light of its objectives, through a system of judicial protection where the reference for a preliminary ruling ensures unity and coherence to the EU law. An external review on the respect of fundamental rights is not strictly excluded, however it shall not interfere with the internal operation of the EU legal system. Therefore, the ECtHR cannot, in particular, decide on the division of competences between the Union and the States and it cannot independently interpret the EU law (at least not without the prior involvement of the ECJ).

We will not analyse here in detail the various reasons of incompatibility identified by the ECJ which prevent, for the time being, a formal and direct accession of the Union to the ECHR. It will be noted, however, that the Kirchberg Judge held the envisaged agreement to be incompatible with Article 6(2) TEU or with Protocol No. 8 EU in that (1) it is liable adversely to affect the specific characteristics and the autonomy of EU law in so far as it (i) does not ensure coordination between Article 53 of the ECHR and Article 53 of the Charter, (ii) does not avert the risk that the principle of Member States' mutual trust under EU law may be undermined, and (iii) makes no provision in respect of the relationship between the mechanism established by Protocol No. 16 and the preliminary ruling procedure provided for in Article 267 TFEU. Therefore, the agreement (2) is liable to affect Article 344 TFEU 'in so far as it does not preclude the possibility of disputes between Member States or between Member States and the EU concerning the application of the ECHR within the scope ratione materiae of EU law being brought before the

Europe (février) 4; Eleanor Spaventa, 'The Protection of Fundamental Rights in the European Union after Opinion 2/13' (2015) 22 MJ 35; Vladimiro Zagrebelsky, 'L'UE e il controllo esterno della protezione dei diritti e delle libertà fondamentali in Europa. La barriera elevata dalla Corte di Giustizia' (2015) 9 Diritti umani e diritto internazionale 125; Françoise Benoit-Rohmer, 'L'adhésion à la Convention européenne des droits de l'homme, un travail de Pénélope? A propos de l'avis 2/13 de la Cour de Justice' (2016) RTDE 593; Sionaidh Douglas-Scott, 'Autonomy and Fundamental Rights: The ECJ's Opinion 2/13 on Accession of the EU to the ECHR' (2016) Europarättslig tidskrift 29. 
ECHR'. Again, (3) the agreement envisaged does not lay down arrangements for $(i)$ the operation of the co-respondent mechanism and (ii) the procedure for the prior involvement of the ECJ, that enable the specific characteristics of the Union and EU law to be preserved. Finally, (4) it 'fails to have regard for the specific characteristics of EU law with regard to the judicial review of acts, actions or omissions on the part of the EU in CFSP matters in that it entrusts the judicial review of some of those acts, actions or omissions exclusively to a non-EU body'. ${ }^{114}$

These are, clearly, profiles of incompatibility that the Commission in primis will have to keep in due consideration in the event that the negotiations regarding the accession reopen. ${ }^{115}$ Article 218(11) TFEU substantially provides for as much, stating that 'Where the opinion of the Court is adverse, the agreement envisaged may not enter into force unless it is amended or the Treaties are revised'. It is improbable that the second prospected solution, i.e. the revision of the Treaties under Article 48 TEU, is chosen; rather, it seems more plausible an amendment of the draft agreement in compliance with the remarks made by the ECJ, and therefore, after a potential new 'check' by the Court, a completion of the accession process. However, these are such drastic remarks ${ }^{116}$ that strictly following them to 'reshape' the draft agreement could mean emptying it of its content and, as a consequence, depriving the accession itself of real meaning. ${ }^{117}$

In any case, what is relevant today is the fact that the ECHR provisions are not (yet) a written source directly binding the Union and its Member States as (also) States of the Union (and not only, singly, as Contracting Parties of the ECHR). Therefore, they continue to be relevant in the EU legal system as an external, exogenous source, entering into it only (i) through the Charter, and most notably through the so-called homogeneity clause pursuant to Article $52(3)^{118}$ or (ii) through the interpretative and creative work of the ECJ as general principles of law (under Article 6(3) TEU), therefore, as an unwritten source. This, moreover, applies not only to the ECHR but also to its additional Protocols, even in

114 Opinion 2/13 Adhésion de l'Union à la CEDH ECLI:EU:C:2014:2454, para 258 .

115 See this ch 1.9 .

116 Less tranchante and, perhaps, easier 'resolvable' was the position of AG Kokott in her View of the 13 June 2014.

117 Sionaidh Douglas-Scott, 'Opinion 2/13 on EU accession to the ECHR:

a Christmas bombshell from the European Court of Justice' <http://uk constitutionallaw.org>, 24 December 2014; Zagrebelsky (n 113) 125 ff.

118 On this subject see ch 22.1 . 
the event that they have not been ratified by all Member States (or that some of them have made reservations), provided that - obviously - their provisions are 'referenced' in the Charter or have relevance through a general principle. ${ }^{119}$ In this regard, the substantial difference with respect to what would occur in the event of accession under Article 6(2) TEU is clearly evident: this, in fact, as indicated above, would regard only the ECHR and the Protocols Nos 1 and 6 to which all the EU Member States have adhered; only such sources could directly bind also the Union and only a violation of them could be censored by the Strasbourg Court.

In light of the present legal framework, the ECJ has also taken a position on the current, and therefore effective, extent of the ECHR in the Union and in the Member States through Article 6(2) TEU. In truth, the EU Judge has formally decided on the interpretation of Article 6(3) TEU; however - failing accession - the very same findings could have been reached also interpreting Article 6(2) TEU.

The Luxembourg Judge - in line with the position expressed by the Italian Constitutional Court ${ }^{120}$ - has therefore $(i)$ excluded the necessary assimilation of the ECHR provisions to the EU provisions with respect to direct effect and disapplication of the conflicting national provision, and (ii) correctly held that defining the relevance of the ECHR in their legal systems is a matter of competence of the Member States.

In the Kamberaj case, the referring (Italian) court asked in essence the ECJ

whether, in case of conflict between the provision of domestic law and the ECHR, the reference to the latter in Article 6 TEU obliges the national court

119 See further Steve Peers, Sacha Prechal, 'Article 52' in Peers, Hervey, Kenner, Ward (eds) (n 25) 1457, $1492 \mathrm{f}$, stressing that the Charter makes also reference to other international conventions that have not been ratified by all the Member States. As already mentioned (in this ch 1.6), reference should be made to the ne bis in idem principle, which is today codified in Article 50 CFR and set forth in Article 4 of Protocol No. 7 ECHR, that does not bind all the EU States.

120 Corte cost., Judgment No. 80/2011, D.P.E. (<http://www.cortecostituzionale. it/actionPronuncia.do $>$ ), para 5.3, providing that: 'The foreseen accession of the Union to the ECHR strengthens the protection of human rights, authorizing the Union, as such, to submit itself to an international system of judicial review with respect to the protection of such rights. [...] Despite any other possible consideration, what is stated in paragraph 2 of the new Article 6 of the Treaty remains, at this stage, still not effective. Their precise identification will obviously depend on the specific ways in which the accession will be achieved' (our translation, emphasis added). 
to apply the provisions of the ECHR (...) directly, disapplying the incompatible source of domestic law, without having first to raise the issue of constitutionality before the (...) (Constitutional Court). ${ }^{121}$

The ECJ set forth that:

According to Article 6(3) TEU, fundamental rights, as guaranteed by the ECHR and as they result from the constitutional traditions common to the Member States, are to constitute general principles of the EU law. That provision of the Treaty on European Union reflects the settled case-law of the Court according to which fundamental rights form an integral part of the general principles of law the observance of which the Court ensures (...). However, Article 6(3) TEU does not govern the relationship between the ECHR and the legal systems of the Member States and nor does it lay down the consequences to be drawn by a national court in case of conflict between the rights guaranteed by that convention and a provision of national law. The answer to the (...) question must therefore be that the reference made by Article 6(3) TEU to the ECHR does not require the national court, in case of conflict between a provision of national law and the ECHR, to apply the provisions of that convention directly, disapplying the provision of national law incompatible with the convention. ${ }^{122}$

Similarly, in the following Akerberg Fransson case, the ECJ affirmed that:

As regards (...) the conclusions to be drawn by a national court from a conflict between national law and the ECHR, it is to be remembered that whilst, as Article 6(3) TEU confirms, fundamental rights recognized by the ECHR constitute general principles of the European Union's law and whilst Article 52(3) of the Charter requires rights contained in the Charter which correspond to rights guaranteed by the ECHR to be given the same meaning and scope as those laid down by the ECHR, the latter does not constitute, as long as the European Union has not acceded to it, a legal instrument which has been formally incorporated into European Union law. Consequently, European Union law does not govern the relations between the ECHR and the legal systems of the Member States, nor does it determine the conclusions to be drawn by a national court in the event of conflict between the rights guaranteed by that convention and a rule of national law. ${ }^{123}$

\footnotetext{
121 Case C-571/10 ECLI:EU:C:2012:233, para 59.

122 Ibid., paras 60-63 (emphasis added).

123 Case C-617/10 ECLI:EU:C:2013:280, para 44 (emphasis added). See also the Opinion of AG Cruz Villalón, paras 107-109.
} 


\subsection{THE IMPASSE OF THE ACCESSION PROCESS AND THE RELEVANCE OF THE ECHR IN THE LEGAL SYSTEMS OF THE EUROPEAN UNION AND OF THE MEMBER STATES IN THE EVENT OF ACCESSION}

The repeatedly mentioned Opinion $2 / 13$ has clearly caused an impasse in the process of negotiation of the accession agreement. A few months following the adoption of the Opinion, the Commission, in response to two parliamentary questions, clarified that it will be necessary to re-negotiate the draft accession agreement owing precisely to the negative Opinion of the ECJ, underlining the need for 'a reflection period [...] in order to examine the best way forward'.124 The Commission added that it

remains empowered by the Council decision of 4 June 2010 to continue the negotiations with the other Council of Europe States. Amendments to the draft accession to be demanded by the EU should be strictly limited to what is necessary to satisfy the additional requirements as to the content of the accession agreement which flow from opinion 2/13. Future negotiations on these necessary amendments will be conducted in consultation with the 'special committee' designated by the Council. The European Parliament will be kept immediately and fully informed. ${ }^{125}$

Meanwhile, on 20 April 2016, the European Parliament held a public hearing in order to seek the opinions of experts on the possibility of reopening the negotiations. ${ }^{126}$ The institution has also commissioned a study to an independent expert (Jean Paul Jacqué) in order to verify such an opportunity. ${ }^{127}$ The study, published in September 2016, concludes in favour of reopening, consistent with the solution suggested by the experts

124 See <http://www.europarl.europa.eu/sides/getAllAnswers.do?reference= E-2015-001195\&language=EN>, 24 March 2015.

125 Ibid. (emphasis added).

126 See <http://www.europarl.europa.eu/committees/it/afco/events-hearings. html?id=20160420CHE00201 > and the additional contributions, that may be found here, of Jörg Polakiewick, Jean Paul Jacqué and Sonia Morano-Foadi and Stelios Andreadakis.

127 The research paper ('L'avis 2/13 de la Cour de Justice sur l'adhésion de l'Union à la CEDH et après?') was requested by the European Parliament's Committee on Constitutional Affairs and commissioned, overseen and published by the Policy Department for Citizens' Rights and Constitutional Affairs, <http://www.europarl.europa.eu/RegData/etudes/STUD/2016/556975/IPOL_STU (2016)556975_FR.pdf>. 
during the public hearing. The study recognizes that Opinion 2/13 highlights the necessity of autonomy of the EU legal system which could be threatened by the accession. At the same time, it also underlines how the lack of accession does not really guarantee such autonomy, since the Member States can still be brought before the ECtHR when they violate the ECHR in applying the EU law; and in such cases the ECtHR can interpret autonomously (i.e. without a previous decision of the ECJ on the matter) the EU law, also in order to determine whether the State is applying the EU law and whether it has a margin of discretion in such application. Therefore, according to the study both Article 6(2) TEU and the risks connected to the current situation play in favour of the reopening of the negotiations by amending the draft agreement to take into account the indications of the ECJ, and to ultimately improve the position (and the protection) of the individuals who claim to be harmed by a violation of the ECHR on the part of the Union. Lastly, the study points out how the most complicated and delicate interventions concern the situation pertaining to the current judicial statute of the CFSP system.

In any case, almost three years after the Opinion, the negotiations have not yet been reopened. As already mentioned, a revision of the Treaties aimed at allowing the signature of the agreement (or of one or more of its parts) in the version reviewed by the ECJ in 2014 does not seem plausible. This is despite the fact that, as noted, such a revision is admissible under Article 218(11) TFEU and would naturally be possible if the States decided to intervene in this sense, actually disregarding the authority of the ECJ with respect to the accession. Even the elimination of Protocol No. 8, although suggested by certain authors, would not be sufficient to allow the approval of the current version of the draft agreement, since the content of the Protocol "ne fait que reprendre pour l'essentiel des principes qui résultent des traités et de la jurisprudence antérieure de la Cour de justice'. ${ }^{128}$

While waiting to verify if, when, and on the basis of which directives the negotiations will start again, we cannot refrain from questioning the

128 Jean-Paul Jacqué, 'L'adhésion à la Convention européenne des droits de l'homme après l'avis 2/13 de la Cour de justice de l'Union européenne', briefing at the above-mentioned public hearing on 'Accession to the European Convention on Human Rights (ECHR): Stocktaking after the ECJ's Opinion and way forward' <http://www.europarl.europa.eu/cmsdata/104501/Briefing_20.04.2016\% 20(2).pdf $>6$. For a list of possible responses to the criticalities singled out in the Opinion see Przemyslaw Tacik, 'After the Dust Has Settled: How to Construct the New Accession Agreement After Opinion 2/13 of the CJEU' (2017) 18 German Law Journal 919. 
real scope of the provision under Article 6(2) TEU. As is known, it provides that 'The Union shall accede to the European Convention for the Protection of Human Rights and Fundamental Freedoms. Such accession shall not affect the Union's competences as defined in the Treaties'.129

Certain authors have identified a binding imperative in the expression 'shall accede'. They believe that the will of the Member States expressed in the Treaty was intended to bind the EU institutions to conclude this agreement, in order to fill the gap in the system owing to the lack of an external review of the work of the EU institutions (including the Court of Justice of the European Union, CJEU). Based on this approach, the breach of that obligation would determine an action against the institutions for failure to act under Article 265 TFEU. ${ }^{130}$ Other authors have speculated that the non-compliance with the above-mentioned obligation and, therefore, the failed accession of the Union to the ECHR, would make the Member States vulnerable to an infringement procedure under Article 258 TFEU. ${ }^{131}$ According to yet a different approach, the potential 'breach' regarding the commitment in question is instead not susceptible to being sanctioned in any way, since it is not only a legal but also a political commitment, involving the Member States as much as the institutions. ${ }^{132}$ In this perspective, we share the view according to which the formula 'shall accede' should be considered a 'qualified commitment of means, rather than a genuine obligation of result' ${ }^{133}$

129 Emphasis added.

130 Florence Benoit-Rohmer, 'L'adhésion de l'Union à la Convention européenne des droits de l'homme' (2011) 19 Journal de droit européen 285; Lucia Serena Rossi, 'Il Parere 2/13 della CGUE sull'adesione dell'UE alla CEDU: scontro fra Corti?' <http://www.sidiblog.org/>, 22 December 2014; Stelios Andreadakis, 'Problems and Challenges of the EU's Accession to the ECHR: Empirical Findings with a View to the Future' in Morano-Foadi, Vickers (eds) (n 26) 47, 66.

131 Steve Peers, 'The CJEU and the EU's Accession to the ECHR: A Clear and Present Danger to Human Rights Protection' <http://eulawanalysis.blogspot. it/>, 18 December 2014; Sionaidh Douglas-Scott, 'The Relationship Between the EU and the ECHR Five Years on from the Treaty of Lisbon' in de Vries, Bernitz, Weatherill (eds), The EU Charter (n 20) 21, 28.

132 Giuseppe Tesauro, 'Bocciatura del progetto di accordo sull'adesione dell'Unione europea alla CEDU: nessuna sorpresa, nessun rammarico' (2015) Foro it. IV-77.

133 Roberto Baratta, 'Accession of the EU to the ECHR: The Rationale for the ECJ's Prior Involvement Mechanism' (2013) 50 CML Rev 1305. 
It is certain that the majority of scholars believe that the accession would ensure, better than the current relationship between Courts, the effective protection of fundamental rights in addition to the certainty and the coherence of such protection. ${ }^{134}$

However, we share the minority opinion of those who believe that the failed accession is not cause for concern. ${ }^{135}$ This is also due to the fact that, following Opinion 2/13, the attention of the ECJ to the protection of fundamental rights appears to have increased, even to the (although limited) detriment of the mutual trust, a fundamental pillar of the EU legal system that characterizes the relations between the Member States. Reference is made, in particular, to the Aranyosi and Căldăraru cases. ${ }^{136}$ Here the ECJ, despite referencing its own jurisprudence N.S. and Others (regarding the matter of asylum) about the possibility of avoiding the surrender of an individual to the authorities of another Member State only under exceptional circumstances, ${ }^{137}$ authorizes the national judges to verify whether, in the presence of information attesting to the existence of systemic or diffused défaillances regarding the protection of fundamental rights, a real risk of violation of Article 4 CFR (corresponding to Article 3 ECHR) for the concerned individual exists. In this way the ECJ (via the national authorities) avoids the person to be surrendered by

134 Peers (n 131); Douglas-Scott (n 131) 29, stating that the Opinion 2/13 'does not take rights seriously'; Polakiewick (n 95) xxvii.

135 Fabrice Picod, 'La Cour de justice a dit non à l'adhésion de l'Union européenne à la Convention EDH. Le mieux est l'ennemi du bien, selon les sages du plateau du Kirchberg' in Semaine du droit, éd. gén - no 6 - 9 février 2015, 230; and before Opinion 2/13, Antonio Tizzano, 'Il nuovo ruolo delle corti supreme nell'ordine politico e istituzionale: la Corte di giustizia dell'UE' (2012) 17 DUE 811; id., 'Notes sur le role de la Cour de justice de l'Union européenne' in Kronenberger, D'Alessio, Placco (eds) (n 20) 223. In favour of the dialogue between the two Courts, without a necessary hierarchical relationship between them, see also Jacques Vergès, 'Cour européenne des droits de l'homme et Cour de justice de l'Union européenne dans la problématique d'un accord d'adhésion de l'Union à la Convention européenne des droits de l'homme: coordination ou subordination?' in Europe(s), Droit(s) européen(s) - Une passion d'universitaire. Liber Amicorum en l'honneur du professeur Vlad Constantinesco (Bruylant 2015) $613,630 \mathrm{ff}$.

136 Joined Cases C-404/15 and C-659/15 PPU ECLI:EU:C:2016:198. Further see Georgios Anagnostaras, 'Mutual Confidence is not Blind Trust! Fundamental Rights Protection and the Execution of the European Arrest Warrant: Aranyosi and Căldăraru' (2016) 53 CML Rev 1675. See also ch 22.4. More recently, the ECJ has also enhanced the protection of individual rights in the field of CFSP: see Case C-72/15 Rosneft ECLI:EU:C:2017:236.

137 Joined Cases C-411/10 and C-493/10 ECLI:EU:C:2011:865. 
virtue of an EAW being likely to be subject to inhuman or degrading treatment in the issuing Member States. ${ }^{138}$ In fact, the Court - in order to ensure the respect of a fundamental right (in compliance with Article 1(3) of Framework Decision 2002/584/GAI) - de facto legitimates (although, as noted, only under exceptional circumstances and following a broad exchange of information between the authorities of the involved States) the reliance on a new ground for refusal in addition to those formally provided in EU legislation, previously considered to be absolute and exhaustive. ${ }^{139}$ Furthermore, the ECJ aligns itself with, or at least gets closer to, the jurisprudence M.M.S. v Belgium and Greece of the ECtHR - then 'integrated' by the more recent decision Tarakhel $v$ Switzerland regarding asylum. ${ }^{140}$

Clearly, if the accession process were completed, overcoming the 'boundaries' set by the negative Opinion of the ECJ, the consequences

138 Joined Cases C-404/15 and C-659/15 PPU ECLI:EU:C:2016:198, para 104, setting forth that: 'Article 1(3), Article 5 and Article 6(1) of Framework Decision [2002/584/JAI] must be interpreted as meaning that where there is objective, reliable, specific and properly updated evidence with respect to detention conditions in the issuing Member State that demonstrates that there are deficiencies, which may be systemic or generalised, or which may affect certain groups of people, or which may affect certain places of detention, the executing judicial authority must determine, specifically and precisely, whether there are substantial grounds to believe that the individual concerned by a European arrest warrant, issued for the purposes of conducting a criminal prosecution or executing a custodial sentence, will be exposed, because of the conditions for his detention in the issuing Member State, to a real risk of inhuman or degrading treatment, within the meaning of Article 4 of the Charter, in the event of his surrender to that Member State. To that end, the executing judicial authority must request that supplementary information be provided by the issuing judicial authority, which [...] must send that information within the time limit specified in the request. The executing judicial authority must postpone its decision on the surrender of the individual concerned until it obtains the supplementary information that allows it to discount the existence of such a risk. If the existence of that risk cannot be discounted within a reasonable time, the executing judicial authority must decide whether the surrender procedure should be brought to an end' (emphasis added).

139 Case C-192/12 PPU West EU:C:2012:404, para 55; Case C-399/11 Melloni EU:C:2013:107, para 38; Case C-168/13 PPU F. EU:C:2013:358, para 36; Case C-237/15 PPU Lanigan ECLI:EU:C:2015:474, para 36.

140 Respectively, App No. 30696/09 (ECtHR, 21 January 2011) and App No. 29217/12 (ECtHR, 4 November 2014). For a similar approach to the ECtHR's jurisprudence in the field of asylum see, more recently, Case C-578/16 PPU C.K. and Others ECLI:EU:C:2017:127 (for further details see ch 2 2.4). 
relating to the relevance of the ECHR in both the legal systems of the European Union and of the Member States would not be insignificant.

With respect to the first matter, the repercussions would occur in particular regarding the relationship between the two Courts and the possible 'survival' of the equivalent protection doctrine set forth in the jurisprudence of the ECtHR. On the basis of this doctrine, as is known, when $(i)$ a Member State acts within the scope of EU law without having any margin of discretion and (ii) there is a 'deployment of the full potential of the supervisory mechanism provided for by European Union law', it is assumed that the EU legal system ensures a protection of fundamental rights that, although not coincident, is at least equivalent to the one ensured by the system of the ECHR; any such presumption can be rebutted if, in the circumstances of a particular case, it is considered that the protection of the ECHR rights was manifestly deficient. ${ }^{141}$

As a consequence, it shall be remembered that, in the event of accession under the not amended provisions of the Treaties (i.e. according to the provisions of the Treaties currently in force), the ECHR would acquire the ranking of sub-primary source in the EU legal system (the accession agreement would in fact enter into force in accordance with Article 218 TFEU), although it would be difficult not to recognize it as the status of primary law and use it, just like the Charter, as a directly binding parameter of interpretation and of validity. ${ }^{142}$ This, in particular, (i) regarding the ECHR provisions corresponding to the ones codified in the Charter and (ii) in consideration of the fact that, following the accession, the violation of the ECHR (and of the two mentioned Protocols) by the EU institutions (bodies, offices and agencies), including

141 See, in nuce, the decision of the Commission of the 9 February $1990 \mathrm{M} \&$ Co $v$ Germany, and then the decision of the ECtHR of the 30 June 2005, Bosphorus Hava Yollari Turizmve Ticaret AS v Ireland, paras 155-157, then referenced and integrated (as the second condition in the text) in the judgment of the 6 December 2012, Michaud v France, paras 101-115, and lastly confirmed in the decision of the 23 May 2016, Avotinš v Latvia, paras 101-112. On this topic see also ch 44.8 .

142 See, e.g. Francesco Bestagno, 'I rapporti tra la Carta e le fonti secondarie di diritto dell'UE nella giurisprudenza della Corte di giustizia' (2015) 9 Diritti umani e diritto internazionale 259, 263. AG Kokott seems to advocate this thesis in her View in Opinion 2/13, para 202, where she states that: 'to conclude from the "intermediate ranking" of this envisaged international agreement between the primary and other secondary law of the EU that the founding Treaties could thenceforth claim unrestricted "precedence" over the ECHR would be to fail to appreciate the special significance of the ECHR for the EU legal order'. 
the CJEU, could potentially be censored by the Strasbourg Court (and from this point of view one might wonder whether the ECHR could even acquire the status of supra-constitutional source $\left.{ }^{143}\right)$. This last consideration has been, without a doubt, one of the main reasons that led the ECJ to boldly reject the draft agreement, thereby securing the autonomy of the EU legal system, including its own interpretative authority. ${ }^{144}$

With regard to the relevance of the ECHR in the legal systems of the Member States after the accession, we will only make a few comments regarding the Italian legal system. The consequences would affect the relationships among the EU and national sources and the principle of supremacy of the EU law. In fact, it would be necessary to distinguish between $(i)$ the cases falling within the scope of application of the EU law and in which the 'communitarized' ECHR may be considered 'covered' by Article 11 of the Constitution ${ }^{145}$, from (ii) the cases that, instead, do not fall within the scope of application of the EU law and, therefore, the ECHR continues to be relevant in the national legal system as an independent source, 'covered' only by Article 117 of the Constitution. ${ }^{146}$ It is not an obvious distinction and it is also confusing for some judges today. ${ }^{147}$ The difference mainly concerns the consequences that can derive from a conflict between a national provision and the ECHR, whether part of the EU legal system or not. In the first case, a conflict with an ECHR provision - if directly effective - can cause the disapplication of the conflicting national provision (as occurs with

143 In the sense that, following the accession, the ECHR would have a value that is 'superior' to the one of the Charter see, e.g. Zdzisław Kędzia, 'Relationship Between the European Convention on Human Rights and the Charter of Fundamental Rights After the European Union's Accession to the Convention' in Barcz (ed.) (n 67) 224, 238.

144 Opinion 2/13, paras 166-200.

145 Which represents the 'solid ground' (since the Judgment No. 170/1984, Granital) of the relevance of the EU law in the Italian legal system: see Corte cost., Judgment No. 227/2010 M.K.P (<http://www.cortecostituzionale.it/ actionPronuncia.do $>$ ). Such provision sets forth that: 'Italy agrees, on conditions of equality with other States, to the limitations of sovereignty that may be necessary to a world order ensuring peace and justice among the Nations'.

146 According to which 'Legislative powers shall be vested in the State and the Regions in compliance with the Constitution and with the constraints deriving from EU legislation and international obligations'.

147 Consiglio di Stato, panel IV, Judgment No. 1220/2010 and, more broadly, T.A.R. Lazio, panel II bis, Judgment No. 11984/2010, setting forth the direct applicability of the ECHR provisions, justifying such solution in light of the entry into force of the Lisbon Treaty (indeed, in the second decision the accession of the Union to the ECHR is wrongly assumed as already accomplished). 
respect to all of the EU provisions directly applicable or having direct effect). In the second case, an immediate disapplication (operated by the national judges) of the national provision conflicting with the relevant ECHR provision would not instead be possible, ${ }^{148}$ since the resolution of potential conflicts must be solved by way of a judgment of constitutional illegitimacy by the Constitutional Court on the basis of the approach explained in the so-called twin judgments, ${ }^{149}$ as specified in subsequent decisions. ${ }^{150}$

148 In contrast, in favour of the possible direct effect of the provisions of the ECHR in the current legislative framework, in consideration of the fact that the ECHR has already accessed the EU legal system through Article 6(3) TEU, see Giorgio Gaja, 'Lo statuto della convenzione europea dei diritti dell'uomo nel diritto dell'Unione' (2016) 99 Riv Dir Int 677.

149 Corte cost., Judgments No. 348/2007, R.A., A.C., M.T.G and No. 349/ 2007, Comune di Avellino e a. (<http://www.cortecostituzionale.it/actionPronuncia. do $>$ ), according to which, where a Convention-oriented interpretation is not possible, recourse to the Constitutional Court should be made in order to declare the constitutional illegitimacy of the national provision conflicting with the provision of the ECHR, upon prior verification of its compliance with the Constitution. After all, the same still occurs - on the basis of the mentioned Granital jurisprudence (n 145) - if the conflict is between a national provision and a EU provision either lacking direct applicability or direct effect.

150 It seems appropriate to mention that, in Judgment No. 49/2015 (on which numerous contributions are available on the website <http://www.giurcost.org/ decisioni/2015/0049s-15.html>), the Italian Constitutional Court seems to have clarified the scope of the mentioned 'twin judgments' confining the relevance of the ECHR case law within the national legal system. The Judge established that the obligation on the national judge with respect to the decisions of the ECHR exists only $(i)$ if the judge is requested to decide on the 'downstream' case with respect to the decision of the Strasbourg Court, (ii) if an established jurisprudence of the Strasbourg Court is relevant for the case at issue, or (iii) if the Strasbourg Court notices a structural and systematic deficiency in the Italian legal system. In light of such approach, it can be wondered whether a broader power of the national judges to verify the violation of the ECHR provision with respect (also) to the constitutional provisions is possible, thereby ensuring $(i)$ the disapplication of the provision that allows the ECHR to access the Italian legal system where none of the three described scenarios occurs, and thus (ii) the application of the domestic law (however also, perhaps, surreptitiously introducing a widespread verification on the respect of the counter-limits doctrine). Also Cassazione penale, panel I, Judgment No. 24384/2015 seems to depict a sort of 'widespread review' in cases in which the judgments of the ECtHR clearly state that a domestic provision conflicts with the ECHR. 


\subsection{THE POSSIBLE ALTERNATIVES TO THE ACCESSION}

As already mentioned, it is not certain at all that the process of accession will actually be resumed and, especially, completed. It does not seem easy, in fact, to overcome the censures of the ECJ; it would have been easier to follow the suggestions of the Advocate General in her View. Further, a new draft agreement could be subject to the scrutiny of the ECJ and we cannot be a priori sure that the outcome would be positive. Nor can we be sure that the legal solutions and the inevitable political compromises proposed would be accepted by those States parties to the ECHR that are not members of the European Union. Lastly, as mentioned, the interruption of the accession process is not considered that alarming: it is in fact certain that the CJEU also protects the fundamental rights satisfactorily and that, as will be better shown below, even possible differences between the jurisprudence of the Luxembourg and the Strasbourg Courts are normally temporary and in any case justifiable (and acceptable) owing to the specificities of the systems in which the relative judgments are rendered. ${ }^{151}$

Therefore, it seems useful to briefly consider certain possible alternative scenarios to the accession that could occur if the European Commission and also the Member States were to consider it preferable to 'take a step back' from the direction that has been followed so far.

The viable paths, not necessarily concurrently, are all meant to ensure (better said, improve) a fruitful and constant dialogue between the two Courts, ${ }^{152}$ to the benefit of the level of protection of the rights of the individual. The existence of a dialogue between the two Courts (formalized since 1998 with regular meetings among the judges of the two judicial bodies), not based on a legal obligation of cooperation, but simply on comity, is recognized by the same intergovernmental conference that drafted the Lisbon Treaty, in Declaration No. 2 regarding Article 6(2) TEU. Here it is highlighted how 'such dialogue could be reinforced when Union accedes to the' ECHR, since it would have become 'institutionalized' ${ }^{153}$ However, the prospected solutions could

\footnotetext{
151 See further ch 22.4.

152 Besides the mutual and progressive influence of the respective jurisprudence, on which see ch 22.2 .

153 On these different forms of dialogue see Sonia Morano-Foadi, Stelios Andreadakis, 'Report on the Protection of Fundamental Rights in Europe: A Reflection on the Relationship between the Court of Justice of the European Union and the European Court of Human Rights post Lisbon'
} 
facilitate the 'osmosis' between the legal systems of the Union and that of the Council of Europe, leading to their mutual enrichment, probably more satisfactorily than a formalized hierarchical system of the relations between Courts. ${ }^{154}$

A first possible alternative to the accession to the ECHR could be identified in the creation of a 'mechanism of cooperation' similar to that foreseen in the Protocol No. 16, ${ }^{155}$ allowing (also) the ECJ to submit a request for a preliminary Opinion to the Strasbourg Court, although, as is known, this would not be binding. 156

A second solution could be the mandatory re-introduction of the Opinions of the Advocate General any time the ECJ is requested to rule on an issue relating (directly or indirectly) to the protection of fundamental rights, and therefore involving, at least potentially, also the ECHR. This solution would entail the necessary subsequent redrafting of the last paragraph of Article 20 of the Statute of the CJEU, which

<http://docplayer.net/21708101-Dr-sonia-morano-foadi-and-dr-stelios-andreadakis. html>, July 2014.

154 In this respect see, in particular, the position of Tizzano stated in the contributions quoted at $\mathrm{n}$ 135. Also Antonio Ruggeri seems to 'sponsor' the beneficial aspects of a non-hierarchical dialogue between the Courts ('La Carta dei diritti dell'Unione europea e le altre Carte (ascendenze culturali e mutue implicazioni)' in Luigi D'Andrea, Giovanni Moschella, Antonio Ruggeri, Antonio Saitta (eds), La Carta dei diritti dell'Unione europea e le altre Carte (ascendenze culturali e mutue implicazioni) (Giappichelli 2016) 1). In favour of the current system of relationships between the two Courts see also Pasquale Costanzo, 'L'uso fatto della Carta dei diritti dell'Unione nella giurisprudenza della Corte EDU', ibid., 121.

155 Elisabetta Lamarque (ed.), La richiesta di pareri consultivi alla Corte di Strasburgo da parte delle più alte giurisdizioni nazionali. Prime riflessioni in vista della ratifica del Protocollo 16 CEDU (Giappichelli 2015). As of 31 August 2017, it has been ratified by Albania, Georgia, Finland, Lithuania, San Marino and Slovenia, lacking however, the filing of four ratification instruments (pursuant to its Article 8) for its entry into force. For an updated situation relating to the executions and the ratifications of the Protocol see $<\mathrm{http} / / /$ conventions. coe.int/Treaty/Commun/ChercheSig.asp?NT=214\&CM=7\&DF=10/10/2015\&CL= ITA $>$.

156 Such a solution, alternative to the accession, had already been proposed by Francesco Capotorti ('Sull'eventuale adesione delle Comunità alla convenzione europea dei diritti dell'uomo' (1980) 63 Riv Dir Int 5, 27), as a more flexible solution compared with the reference for a preliminary ruling that the ECJ could have brought before the Strasbourg Court, proposed by Giuseppe Sperduti ('Le rattachement des Communautés européennesà la Convention de Rome sur la sauvegarde des droits de l'homme et des libertés fondamentales' (1980) $23 R M$ C 170). 
currently allows the Court not to resort to the said Opinions if the case does not raise a 'new point of law'. Obviously, such a solution would need to be carefully evaluated, especially to the extent that it could cause a new increase of the cases in which the Opinions of the Advocate General are necessary, and a subsequent extension of the duration of proceedings, in contrast with the most recent amendments of the Statute and of the Rules of Procedure of the EU judicial bodies, ${ }^{157}$ aimed, on the contrary, with different solutions, at shortening the length of trials to ensure their reasonable duration. Therefore, if it were decided to proceed in this way, it would be necessary to guarantee an adequate balance among the various needs implied in Article 47 CFR, the effective legal protection of the rights of the individual and the reasonable duration of trials.

A third and final option capable of promoting a better dialogue between the two Courts could be identified in the introduction of a mechanism aimed at allowing an intervention as amicus curiae of the ECtHR or of the Committee of the Ministers of the Council of Europe in cases (directly or indirectly) related to the protection of fundamental rights and, therefore, implying also a potential relevance and interpretation of the ECHR. Even in this case - as in the one just examined - an amendment to the Statute of the CJEU would be necessary, while the first alternative could perhaps be carried out without amending the Treaties, by potential integration of the sole Rules of Procedure of the ECJ.

157 See further Marc-André Gaudissart, 'La refonte du règlement de procedure de la Cour de Justice' (2012) 48 C D E 603; Chiara Amalfitano, Massimo Condinanzi, Paolo Iannuccelli (eds), Le regole del processo dinanzi al giudice dell'Unione. Commento articolo per articolo (Editoriale Scientifica 2017). 